University of Rhode Island

DigitalCommons@URI

Open Access Master's Theses

1962

\title{
United States Foreign Policy in the Far East as Revealed in the MacArthur Hearing
}

Sara Stauffer Whaley

University of Rhode Island

Follow this and additional works at: https://digitalcommons.uri.edu/theses

\section{Recommended Citation}

Whaley, Sara Stauffer, "United States Foreign Policy in the Far East as Revealed in the MacArthur Hearing" (1962). Open Access Master's Theses. Paper 1793.

https://digitalcommons.uri.edu/theses/1793

This Thesis is brought to you for free and open access by DigitalCommons@URI. It has been accepted for inclusion in Open Access Master's Theses by an authorized administrator of DigitalCommons@URI. For more information, please contact digitalcommons-group@uri.edu. 


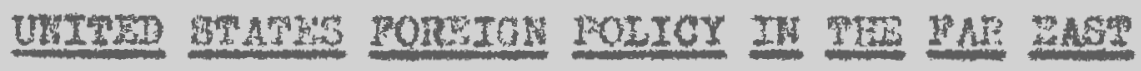

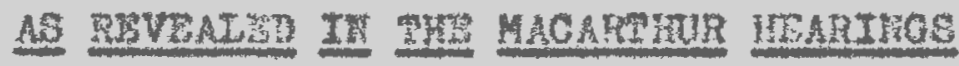 \\ ar \\ SARA THAPYZR WHALET
}

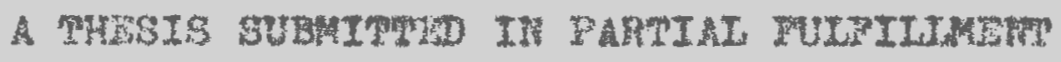

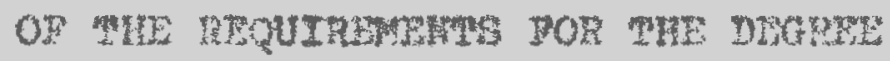 \\ OF MASTH OF ARAS \\ IN \\ POTINICAI SCIENC:
}

UHIVERSITY OF RODE IS工筷D

1962 
ABSTRACP

The hearings on General Douglas MacArthur's dismissal conducted by the United States Senate Committee on Foreign Relations and Committee on the Armed Services were concerned with the relationship between the civil and the military, the comparable importance of Europe and Asia, and the validity of the concept of limited war. This thesis is an examination of the general's actions and statements which caused President Truman to doubt the effectiveness with which the seneral could carry out the policies of the Unfted States and the United Nations. It also examines American policy toward postwar China and actions taken during the Korean war as they were discussed in the hearings. The eftects of American relations with its ellies, the Soviet Union, and the United Nations on the Korean action are also discussed.

After reading articles in the Congressional Record, The General and the President by Rovere and Schlesinger, and other general works, the writer of this thesis studied the published comittee hearings which supplied the main part of the material used in the thesis. When additional clarification was needed, books such as Walter Millis" Arms and the State or Truman's Memoirs were holpful. 
Prom the testimong given before the seate comittees, 1t is concluded that the President bad justiflable reasons for disniesing Douglas Machrthur, athough it deference to the general ts past service to the country, he might have asked the general to resign.

President rruman acted in the interest of the free world when he committed Anerlean troops to sare gouth Korea from the Comunists, although the necessity for such action - Ight have been avolded had the adminictration, Congress, and the country been willing to spend more money for deterrent arms and forees in areas of probable eondzlet. Under the conditions existing at the time. Truman's efforts to Iimit the war action to Korea and to give priority to Burope as the area where it was most important to maintain strength for the containment of Soviet expansioniam vere comendabie. 


\section{ACXNOWLEDGMENTS}

The writer would like to thank Dr. David Warren for his continued help during the writing of this thesis. By offering sugrestions on the writing of the thesis and in correcting the manuscript, Dr. Daniel Thomas was also of substantial assistance. The writer would also like to express her appreciation to the members of the staff of the University of Rhode Island Iibrary for their invaluable help in obtaining information for the thesis. 
TABLE OF COFTENMS

Chapter ${ }_{\text {I. IMRRONUCTION!............... Page }}$

II. POSTWAR RELARIONS IN THF FAR FAST . . . . 5

Victory over Japan

The Yalta Conference

Stilwell and Hurley in China

State Department Officials in China

The Marshall and Wedemeyer Reports

American Aid to the Nationalists

III. THE TORTAT WAR . . . . . . . . .

Postwar Horea

Invasion of South Korea

Collective Action in Korea

The Communist Chinese Invasion

An lntirely New yar

IV. THE RECALI . . . . ..........

MacArthur'g Return to the United States

Differing Views on Formuaa

The December 6 Directive

Differences of Opinion on Military Matters

Letter to Joseph Niartin

V. POLICY AND TACTICS IN KORTA .......

Differing Aims of MeArthur and Truman

Fconomic and Naval Blockades

Bombing Manchuria

Formosa

The Military and the Civilian 
VI. OMHER NATIONS AND MH KOREAN HAR . . . .

Tussia

The United Nations in Korea

The Allies

Burope versus Asia

VII. CONCLUSION . . . . . . . . . . . A. PINDIX

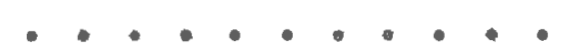




\section{CHAPMER I}

\section{INRRODUCTION}

On April 17, 1951, General Douglas MacArthur returned to the United states after an absence of fourteen years. Six days earlier the President of the United States, Harry S. Truman, had dismissed him with the explanation, "General of the Army Douglas Machrthur is unable to give his wholehearted support to the policies of the United States Government and of the United Nations in matters pertaining to his official duties." I

Voctferous denunciations of and arguments asainst the President's action immediately burst forth. Republicans demanded permission for the General to speak before a joint session of Congress. In caucus, they discussed the possibility of impeaching Mr. Truman. Senator Richard Nixon suggested a Senate censure of the President and pressure on him to restore MacArthur to his command. Senator Kenneth wherry introduced a resolution providing for an investigation of the General's removal. In short, most Republicans were out to make as much political capital as possible out of this abrupt dismisgal,

$1_{\text {Harry S. Truman, Memolrs, Vol. II: Years of Mrial }}$ and Hope (New Fork: Doubleday and Co., 1956), p. 449 . See page 107 of appendix for excerpts from Truman's address to the nation. 
although a few istern republicans, James Duff and

Leverett Saltonstall, for exarple, supported Trumar. I

Meanwhile, Democrats were seeking to identify

Hackrthur and the conservative Republicans with a plan

for forcine a major war with Chira, althoust southerm

Democrats were, in many cases, less than enthusiastic

in their support of Truman. Senator Tom Connolly,

Chaiman of the Senate Foreign Relations Committee, and

Senatar lichard Russell, Chairman of the Senate Armed

Services Commitiee, both supported Truman. Senator

Russell soon announced an investieation by his committee of the facts behind racirthur's dismissal. ${ }^{2}$ when it

becare obvious that the country was interested in more

than the military aspects of the question, the Foreign

Kelations Comittee expressed an interest in participating

in the hearines. A unanimous consent decree was intro-

duced by Senator Russell on April 25 and the hearings began on May 3.3

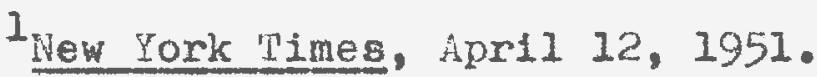

2Ibia., April 16, 1951.

3 Members of the Committee on Armed Services were
} Richard B. Russell, chairman, Harry F. Byrd, Lyndon B. Johnson, Lstes Kefauver, Lester C. Funt, John C. Stennis, Russell 3 . Long, Styles Bridges, Leverett Saltonstall, Wane Morse, William F. Knowland, Herry Cain, Ralph rlanders. On the Comittee on Forefgn $R_{e}$ lations were Tom Connally, chairman, Valter $\$$. Geore, Theodore Francis Green, Brien Mchahon, J. William Fuibright, John J. Sparkman, Guy Gillette, Alexander Wiley, H, Alexander Smith, Bourke Hickenlooper, Henry Cabot Lodge, Ir., and Charles Tobey. 
On April 19 General MacArthur appeared before a joint meeting of Congress and forcefully presented his views to the world. In this speech and in the opening days of the hearings, it became evident that there were three main issues to be aired before the comittees. These were the old argument of civil versus military control, the comparable importance of surope and Asia, and the extent to which a limited war, as compared to a largescale war, could achieve American objectives. ${ }^{1}$

One of the main problems connected with the hearings and the one which prevented them from being held in public was that of revealing classified information. Transcripts of the sessions were reviewed and censored by a military officer and by a legal adviser to the State Department beiore being turned over to the press. General of the Army Douglas MacArthur was the firgt witness, followed by Secretary of Defense George C. Marshall, and then by General of the Army Omar Bradley, Chairman of the Joint Chiefs of Staff. The comittees next questioned the chiefs of staff of the services: Army General J. Lawton Collins; Alr Force General Hoyt S. Vandenberg; and Admiral Forrest P. Sherman, Chief of Naval Operations. Secretary of State Dean Acheson appeared to answer political questions. Lieutenant General ilbert C. Wedemeyer, Former Secretary of Defense Iouis A. Johnson, Vice hamiral Oscar C. Padger, Major General

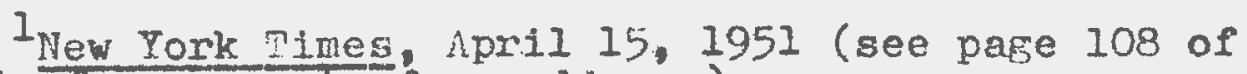
appendix for excerpts from address). 
Emett O'DonnelI, Jr., and Major General David C. Barr were the other witnesses. 
POSTALR MEIATIUNS IN WUE PAR WASP

\section{Victory over Japan}

Although tie feneral purpose of the hearings was supposed to be the weighing of General hacArthur's removal, Republicans earerly took the occasion to berate the adninistration for allegedy losing China after vorld war II. Democrats joined the Republicans in questioning George Parshall, Dean Acheson, Albert Hedemeyer, and Patrick Hurley to ascertain whether our post-war policy was justifiable under conditions existing at the time. The questions ranged from the contributions of Comprist Cina in the strugele against Japan through the "corcessions" of Yalta and the American role in the formation of a coalition Eovernment of vationalists and Combunists in China.

Upon taking the stand, Secretary of state yoan Acheson spent several hours explairireg the administration's policy in Asla after 145, including an outline of the historical background of the Crimean Conference at lalta. After it was seen thet there was insufficient time in the hearings for one of tre participants of the conference, w. Averell larriman, to testify orally, Senator Brian Mchahon called for a written report by lix. Harriman. 
Because the sworn statement which he submitted to the comittee is a good summary of the administration's position on post-war events, it will be used in this paper, together with Dean Achesor's testimony, as a basis for explaining the official policy of the United States. ${ }^{1}$

Russian soldiers and civilians had fought the German invader with courage and pexseverance. By keeping approximately 199 German divisions and 50 divisions of the other Axis countries cngaged in the East, the Soviet Union had eased the cangers of the Formandy invasion. This invasion wight, indeed, have been impossible without this other front in the East. ${ }^{2}$ Because of the strength of the Soviet Union, President Roosevelt and Frime Minister Churchill realized the importance of maintaining sood relations with this nation during the war. 3

In February 3945 the administration believed that Russian participation in the struggle against the Japanese would be necessary to ensure victory. Because of their ambition to maintain influerce over Manchuria, the Russians would have attacked the Japanese there in any event. The

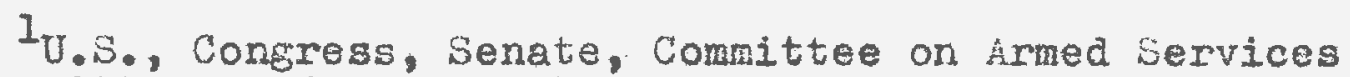
and Committee on Foreign Relations, Hearin,s, The Military Situation in the Far sast, 82d Cone. Ist Sess., 1951, pp. 3328-42. Hereafter noted as Military Situation in the Far East.

Ibid. D. 3329.

3Ibla., pp. 1878-79, Acheson's testimony. According to Senator wayne forse this would account for communications which might seem overconciliatory in the light of later events. 
iaportant question at Yalta was whother they would do so soon enough to save American lives, a question which could only be decided by assessing the costs of a victory over Japan. 1

In support of his thesis of the uncertainty of victory in Japan, Acheson referred to the entrance of American troops in Manila on the First day of the Yalta Conference, with the decisive battles of Iwo Jima and Okinawa still aiead. Information available showed that the Japanese still had a fighting force of five million men. lanned strategy for an assault on kyughu in the fall of 1945 and a landing on Honshu as late as the spring of 1946 would have involved an American force of approximately five million men, of which it had been estimated that casualties might be as high as a milition. 2

Harriran pointed out that the primary source of information which Roosevelt had at the Yalta Conference was a memorandum of the Joint Chiefs of Staff of January 23, 1945 , that "Russia's entry at as early a date as possible consistent with her ability to engage in offengive operations is necessary to provide maximum assistance to our Pacific

\section{${ }^{I_{\text {Ibid. }}}$ pp. $1375-76$ and 3332.}

${ }^{2}$ Ibid., p. 1985. In an article on this part of the hearings in the New York Times of June 21, 1951, the correspondent stated that the figure of a million casualties mentioned by Acheson as necessary to subdue Japan was fantastic, thrt this would have exceeded all American casualties in the war. Later in the hearings, Patrick Hurles blamed Acheson for the figure, although it had been published by Secretary of war itimson on the basis of military advice given nim. 
operations." 1 The Joint Chiefs of Staff were unanimous in the belief that a Russian comittal in the Far East was 3 "very escential factor" in bringing the war to an early end; as military leaders, they considered that a campaizn by the Soviet Union asainst the Japanese in Nanchuria and Korea was necessary. 2 Also, General MacArthur hit very strongly urged a landing on Japan as a means of concluding the war, and according to General Marshall, such an action would have required support from Russia. 3

In support of the need for Pussian intervention, Marshall emphasized the determination of the Japanese to fight until the end. When Japanese representatives in Axis and neutral countries of lurope had appealed to the Prime Minister of Japan to work for an armistice, he had mentioned the difficulties of formulating surrender proposals in view of the intransisence of the Japanese army. It was the opinion of the Joirt Chiefs that only a tremendous pressure or an extraordinary shock offered any hope of ending the army's rule in Tokyo. 4

jome witnesses, e. g., Patrick Hurley, testified that it was known or should have been known at the time of Yalta that the atoric bomb should produce the shock needed to topple the enemy army from power. Senator McMahon, chairman of the Atomic bnerey Comittee, immediately refuted Hurley's statement and quoted a remark of General Leslie

$$
\begin{aligned}
& { }^{1} \text { Ibid., p. 3332. }{ }^{2} \text { Ibid., p. 563. }{ }^{3} \text { Ibid., p. } 564 . \\
& { }^{4} \text { Ibid., pp. 560-62. }
\end{aligned}
$$


Groves, wartime administrutive head of the atomic bomb project, that the scientists had often felt on the brink of failure. I Adrinistration officials held that not until five montis after Yalta aid the first explosion take place in liew fiexico, and scientists even then were not sure trat the boab would be successful. 2 It would thus seem that although one mient well agree with a statement by Macirthur that the United states did not need Russian support after the bomb was dropped and trat the soviet Union's contribution in Asia was regligible, it was by no means evident at the time of Yalta that the bomb would be of any practical use.

In support of the view that the belief in the need for Russian intervention was widespread, Senator hchahon read a speech by Republican flexander wiley which was eiven on July 25, 1945, lone after Yalta, in which wiley decidedly advocated Russian intervention. 3

I Ibia., p. 2095 . In ari answer to a letter from sen. Iickenlooper on this subject, It. Gen. Groves asserted that Stimson had informed Roosevelt of a ninety-nine per cent certainty on tie pert of the scientists that the atomic bomb would be successful and very powerful. (1bie., p. 3119).

Ibid. p. 229. In an article in the New York Times of June 30, ig5i, Wiliam L. Laurence agreed with the administration on these points: few sciertists thou the bomb would be powerful and effective; most believed that the explosion at Alanagorâo would have little force; and with only three bombs in existence, it was unlikely that one of them would have been wasted if there was certainty of the success of the experiment.

3 Ibid., pp. 2060-62. 
The Yalta Agreement

This belief in the need for Russian help against the Japanese led to the inclusion of those controversial provisions of the Yalta hreement conceming areas in the Far Last in which Russia claimed an interest. In his explanation to the Committees, Harriman explained that stalin outlined the Soviet political objective in the Far last in 1944 as the reestailishment of the approximate situation which had existed before the 1905 Russo-Japanese Var. The proposals which stalin then made formed the basis for the discussion at Yalta. ${ }^{1}$

Much criticigm has been leveled at the failure to invite Chian: Kai-shek to take part in the conference and to the stipulations in the treaty that he was not even to be informed of the terms dealing with China. Acheson explained his absence as necessary, due to Stalin's insistence trat the Yalta Conference would deal mainly with the war in iurope. Keeping chiang in ignorance was based on prior experience, for whatever was known in Chungking eventually reached the Japanese; Stalin was unwilling to risk aisclosure of his plans to Tokyo before his isian forces were strengthened. 2

IIbid., p. 3611. The only diflerence between italin's first proposals and the final agreement was that Dairer was made an international port rather than being leased to Russia. The day after Roosevelt and Btalin agreed to the terms, Churchill concurred.

Ibid., p. 8832. 
After quotine from a book by dward stettinius relatine how hoosevelt's death prevented him from reporting the Yalta terms to Chiang, senator H. flexarder smith asserted thet "we did not play fair with our own ally" and made China pay the price for Russia's entrance into the war. Again Acheson countered that Russian help was believed necessary before an attack could be rade on Honghu. 1 Although the clause that claims of the soviet Union in the Far East should be "unquestionably fulfilled" seemed to some to be a betrayal of China, Roosevelt had been convinced that the requirement of China's eventual concurrence had qualified this phrase. According to scheson, the terms of the agrecment (which were, fin tis orinion, in the long-term interest of (hina) had never been contested by Chiang. 2 When the Generalissimo was notified of the Yalta Acreenent on June 15, 1945, he proceeded to araw up an arrangement with the Soviet Union.

Gerieral dedemeyer painted a different picture of Chiang's reaction to Yalta. From personal conversations with Chiang he knew the shock and hurt felt by him because of the Crimean arrangements. 3 when questioned on the subject of Chiang losine face, especially in fanchuria, because of Yalta, Acheson said he did not believe that this was so. He pointed to tise long time which it took Chiang's forces to

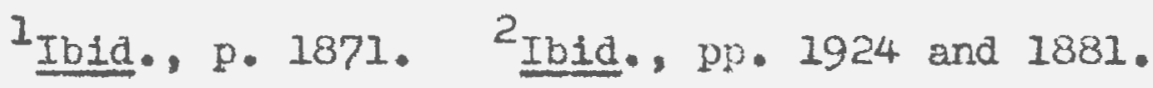
3 New York Times, June 13, 1951. 
reach Manchuria after the armistice; he belioved it would have been impossible for the Nationalists to have reached Manchuria at the end of the war to administer the surrender of 700,000 armed Japanese and prevent the territory from falling into the hands of the Russians. 1

A controversial provision of the agrement was the control given to Russia over Dairen and Port Arthur. When Senator Hickenlooper spoke of this as granting extraterritorial rights in violation of the Atlantic Charter, Acheson admitted that we had had to use our efforts to obtain Chiang's concurrence on this question. 2 When questioned by Hickenlooper on this subject again later in the hearings, Acheson replied that he did not believe that China was deprived of the use of these ports at Yalta and that a cooperative relationship might have been formed as it was in the case of Dairen. 3

When Patrick Hurley spoke before the investigating comittees, he aroused further controversy by maintaining that Roosevelt was sick at Yalta and that the Agreement did not represent his bellefs. According to Hurley, Roosevelt had comissioned hin to try to soften or even set aside the Yalta Agreement, and to do this, had sent him to London and Moscow. By the time he reached Teheran, Roosevelt had died. Under orders from President Truman to continue, he met Stalin and discussed the Yalta Agreement with him. Admitting

$$
\begin{aligned}
& 1_{\text {Military Situation in the Far Esst, pp. 1871-72. }} \\
& { }_{\text {Ibld., p. 1885. 3Ibid., p. 2229. }}
\end{aligned}
$$


that he left these meetings with the Russian leader overoptinistic about the possibility of warding off 111 effects resulting from a possible increase in Russian power, Hurley claimed that he might have been able to do something if the State Department had not intervened. He had made a dent in the armor of the British and Russians, but could not persuade the State Department of any changes needed in the Agreement. ${ }^{1}$

\section{St1lwell and Hurley in China}

Much of the hearings was concerned with the Comunist conquest of China. In 1944 General Joseph stilwell, principal American officer in China, becrme convinced that if the forces of ceneral Chiang Kal-shek were to be effective against the Japanese, they would have to be brought under American directior. He also believed that Nationalist forces which had been withdrawn from the struggle against the Japanese to fight the Communists should once again take the offensive againat the foreign enemy. ${ }^{2}$ General Fatrick Hurley was appointed personal representative of President Roosevelt in August 1944 to adjust differences between Coneral Stilwell and chiang Kai-shek.

I Ibid., $\mathrm{pp} \cdot 2885-88$.
$2_{\text {According to ceneral Hedemeyer, the actual contribu- }}$ tion of the Chinese Communists in the struggle against Japan was limited. On the other hand, neither was the number of Nationalist troops occupied in fighting the Communists very large (ibid., pp. 2208-99). Secretary Marshall gave a different interpretation of Nationalist contributions; he thought the record showed stilwell's belief in too great an involvement of the Nationalists against the Communists to be true (1bid., p. 460). 
According to Hurley, just as Chiang was about to accept the American proposals, he received a telegram from Roosevelt. Considering this message an ultimatum, the Generalissimo wrote an aide-memoire to the American president pointing out his differences with stilwell and stating his belief that the American lacked military judgment, as was evident from his refusal to conduct a full campaign in Burma. ${ }^{1}$ He soon requested Stilwell's recall.

After a visit to Molotov in Moscow, Hurley was much impressed with Russian sincerity and reported to hashington not only that the Soviets would welcome united states aid in the unification of China, but also that the Soviet Government was not responsible for the internal developments of China. While discussing the problem of Fusso-Chinese relations with Chiang, Hurley gave the Chinese leader the impression that Russia would leave Chinese affairs alone. The Mationalists could even negotiate with the Chinese Commint Party, gince it was a eroup without foreicn entanclements. 2 Because of this information on the independence of the chinese Communists from Moscow, Chiang did not feel it necessary to adjust greatly his proeram to please the Commuists; without Russian support they would have had to accept his terms.

After a meetine with Mao rse-tung, chief of the Chinese Comurist Party, General Hurley brought back to

${ }^{1}$ Ibid., pp. 2868-72. ${ }^{2}$ Ibia., pp. 2864-65. 
Chungking a five-point program for settlement with the Communists. The Communists evidently hoped to use these negotiations to political advantage before consenting to military integration. The struggles between the NationalIsts and the Communists for control of territory surrendered by the Japanese began after August 15, 1945. With American assistance, the Nationalists moved into Manchuria and were able to take over many cities and railroads. They were not, however, able to gain complete control of the countryside. They had asked the Russians to delay their departure from Manchuria to enable Chiang's forces to gather in the area. Later, when General Marshall was discussing an agreement for a cease-fire between the Nationalists and Communists in 1946, it was decided that the Nationalists were to move into Manchurla. However, the Communists took advantage of the first opportunity they had to wove into the vacuum. I

In his testimony General Marshall spoke of rumors that Soviet troops were removed from Manchurla in such a way that the domination by the Communists was assured. 2 In discussing ways in which the growth of Chinese Communism could have been halted, Ceneral Wedemeyer testified that at the end of World War II he had wanted to put United States divisions in Manchuria to set up a barrier against the Soviet Union, but that MacArthur had refused to make them available because of a probable need for them in the occupation of Japan. 3

\footnotetext{
${ }^{1}$ Ibid., p. 1918. ${ }^{2}$ Ibid., pp. 696-97. 3 New York Times, June 13, 1951.
} 
State Department officials in China

Meanwhile some Foreign service officers and others in Chins were reporting to the Department of state that the Kuomintang was becoming steadily weaker, while the Commnists were increasine in streneth and receiving nore and more popular support. The sharpest criticism of State Department personnel was read by Senator Smith from Hurley's letter of resignation in 1945 in which he alleged:

While these objectives had the support of the President and the secretary of state it is no seret that the American policy in China did not have the support of all the career men in the State Department. The professional Foreign Service men sided with the Chinese Communist armed party and the inperialist bloc of nations whose policy it was to keep China divided against herself.

In his testimony General wedemeyer agreed that his four political advisers--John Davies, John Emerson, Raymond Iudoen, and John Service--submitted memoranda which invariably criticised the lationalist Government and praised the communist regime. 2 He admitted, kowtere, that the career men seemed to be very intelligent and experienced, and when questioned on this point by Senator Russell, conceded that they were not any more critical of the Chinese Nationalists than he had been in a speech in 1947 before a Jenate committee. 3

In his testimory before the Committees, General Hurley reported finding the career men actually passing

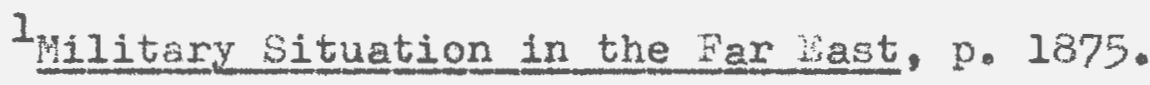
2 Ibid., pp. 2401 and 2496. ${ }^{3}$ Ibid., p. 2524. 
secret information to the armed Chinese Communists. He quoted a report of John Service to General Stilwell, which Hurley had obtained frow a Chinese Communist, in which the Foreign Service officer had expressed the opinion that the United States should take a more realistic line in China and realize that the Kuomintang was in a crisis with its prestige at its lowest point. Nevertheless, Service' most extreme statement in this report seens to have been that the "Kuomintang is dependent upon America for survival, but we are in no ways dependent on the Kuomintang." I When confronted with Kurley's statements on the Communist leanings of those in the State Department's service in China, Dean Acheson recalled extended hearings before the Senate Foreign Pelations Comittee on this question. He remarked that he thought the view then put forward was that General Hurley was mistaken in what he said.? Were American personnel aware of the nature of the Chinese Communists during and after the war? Senator Knowland maintained that they were nat; he quoted from a report of Raymond Ludden that "the so-called Communists are

$1_{\text {Ibid., pp. 2911-12. General Hurley later accused }}$ Service of being pro-Communist and of delivering important State Department documents to Philip Jaffe, editor of the magazine Amerasia and allegedly communist. Service had once suggested that America be prepared to arm any Chinese forces which could be used effectively, since the Americ an purpose was to maintain a degree of flexibility which would permit cooperation with anyone furthering a "united, democratic, friendly China (ibid., pp. 2929-30)."

$$
\text { Ibid., p. } 1875 \text {. }
$$


agrarian refomers of a mild democratic stripe nore than anything else. . ." Acheson maintained that the first concern of the American personnel in China was in serving United states interests ard that during the war their first effort had been to try to bring all forces in china together to fight the Japariese. He knew of no state Depertment people who considered the Communjsts merely agrarian reformers; on the contrary, in their reports they referred to Moscow training and to the Marxist rigidity of the Chinese Communists. 2 General Barr testified that he did not find any State Department personnel dealing with the Communists, at least when he was in China. 3

After General Hurley's diatribe against the "Communists" in the state Department and his avowal that he had always realized the daneers of Communism, Senator McMahon pointed to several instances when furley had advocated appeasement. In a speech on November 29,1945 , the General had stated that the "only difference between the Chinese Communists and Oklahoma Republicans is that the Oklahoma Republicans

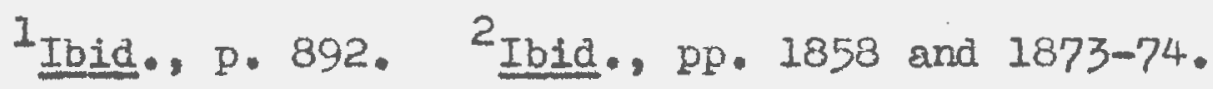

3Ibla., pp. 2971-72. All those appearing before the two comittees maintained that they had always known the nature of Chinese Communism. Answering Sen. Bridges' query on whether the War Dept, had not reported in 1945 that the Communists were definitely not asrarian reformers, sec. Marshall testifled that when he went to China and looked over the situation, he had no doubt but that the leadership of the group was Marxian communist, especially after seeing a hugh picture of Lenin and stalin at Yennan. He recalled Chou-En-lai protesting in 1946 against some Chinese dragging Stalin's portrait through the mud (1bid., pp. 377-78). 
aren't armed." Hurley defended hinself by saying that McMahon had quoted out of context; what he had said referred to a period while the war was still going on and when it was necessary to et the Chinese Communists and Nationalists together against Japan. ${ }^{1}$ However, the war and the need for uniting against Japan were over at the time Hurley made this speech in the latter half of 1945.

The Marshall and Wedemeyer Reports

In a general statement on China at the beginning of his testimony, Secretary of State Acheson stressed the fact that American aid could not of itself insure the survival af recipient government, that the power of decision rested with the government and with the people. In pointing out moments of decision in China after the war, he spoke first of the task of extending the authority of the chinese throughout the nation. In his report of November 1945 General idedemeyer protested that the staff of the Generalissimo had not fully appreciated the importance of logistic and transportation support of the troops in Manchuria. Wedemeyer had also advised Chiang to concertrate on stabilizing the situation in South China through reform and, with the assistance of foreign administrators and technicians, to try to concentrate his military efforts in North China, not Manchuria, reaching an agreement with the Commists in the area. ${ }^{2}$ Reporting that the Nationaliat Government was

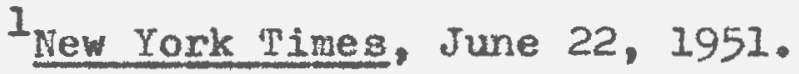

${ }^{2}$ Military Situation in the Far Last, pp. 1840-42.
} 
completely unprepared for the occupation of Manchuria in the face of comunist opposition, General Hecomeyer further sugrested that the rationalists would have to come to an afreement with the Russians on their respective positions in Manchuria. ${ }^{1}$

Wher open civil war broke out between the Communists and lationalists in North Ch1na in 1945, there were several positions the United states could have taken. In his testimony lean Acheson said that one action could have ben for America to pull out completely. However, this might have peraitted the Japanese, who still had considerable influence and strength in the area, to take over the divided country. The altermative of contributing unlinited aid to help the Nationalists was contrary to the wishes of the American people. Thus Haskington chose a compronise position of giving important economic aid to the Chinese Nationalists. and offering assistance in working out an agreement. 2

General Marshall vas to go to China to implement the American policy as it had been outlined in a memorandum to tre War Depuntment by Secretary of State Byrnes. The memorariun stated that our long-range goal was "the development of a strone, united, and democratic China." In order to further this development, dissident elements in the country should "approach the settlement of their differences with a cenuine willineness to compromise." Chiang Kai-shek's

$$
\begin{aligned}
& I_{\text {Ibid., p. } 461 . \text { Mhis was on lioverber } 20,1945 .} \\
& { }^{2} \text { Inid., p. 1842. }
\end{aligned}
$$


government afforded the most satisfactory base for a democracy, although it should be broadened to include representatives of other organized eroups in China. ${ }^{1}$

In his instructions, iruman asked Marshall to try to persuade the Chinese Government to call a national conference of representatives of major politicsi elements to brins about the unification of China. He mentioned that a Feople's Consultative Council (PCC) which included the Chinese Communists was already in session in Chungking. The Fresident Eave Marsheli permission to speak with the utmost frankness to Chiang Kai-shek and other loaders to the effect trat "a China disunited and torn by civil strife could not be considered realistically as a proper place for American assistance along the lines enumerated." 2

\section{Cosition Government in China}

During his testimony Marshall acmitted that he had had only a vague concept of the changes of government in China or of the single party as conceived by Sun Yat-sen. He acquired nost of his working knowledge on these subjects during his flight to China. ${ }^{3}$ soon after his arrival, the American representative was successful in securing an agreemant calling for the cessation of hostilities. To supervise the execution of this Iruce Agreement of January 1 ,

I Ibid., pp. 3134-85. Marshall testified that Byrnes, Undersecretary of State Acheson and John Carter Vincent, head of the China group in the state jepartment, had probably drawn up this report.

$$
{ }^{2} \text { Ibid., p. 3185. 3 }{ }_{\text {Ibid., p. } 548 .}
$$


1946, representatives of the Chinese Communist Party, the Nationalist Covernment, and of the United States set up headquarters in Peiping. iruce teams composed of the three groups were also to be sent into the field to make sure the terms were carried out. The Feople's Consultative Council adopted resolutions calling for the reconstruction of the State Council and for the convocation on May 4, 1946, of a National Assembly to adopt a permanent constitution. 1

Much discussion in the hearins centered about who exactly had advocated the formation of a coalition government. Marsial said thet the first united states sugrestion for Communist participation in the Governmert was made by Ambassador Clarence Gauss when in 1944 he suggested to Chiang the possibility of a war council. 2 In November of that year General Hurley took active measures to help form the coalition. 3

One minor argument of the hearings was whether a telegram approved by MacArthur, Wedemeyer, and Raymond A. Spruance, commander of the 5th Fleet, indicated support of a coalition government. Acheson read the telegram, which outIined moves the military advocated in China and then suggested that American assistance to China "be made available as basis for nesotitation [ $[1 \mathrm{f}]$ by the American Ambassador to

$I_{\text {Harold Vinacke, Far Eastern Politics in the Post-war }}$ Period, (New York: Appleton, Century-Crofts, Inc., 1956), pp. 108-09.

Pilitary jituation in the Par East, p. 544.

3. Ibid., p. 1919. lestimony of Dean Acheson. 
bring together and effect a compromise between the najor opposing eroups in order to promote a unitea, democratic China."I Machthur responded that it was beyonc belief to infer support of a coalition government from one small paragraph attached to technical report. As proof that this telegram was not viewed in 1946 as a support of a coalition Bovernment, Mackrthur telegraphed the Committees that Marshall had not mentioned the telegram when the two met soon thereafter. According to MacArthur, the effect of the Marshall mission (to use hmerican assistance as a weapon to force an alliance with the Comaunists) was the exact opposite of the ideas of the MacArthur-Hedeneyer-Spruance telegram. 2

General Wedemeyer also asserted that the paragraph was taken out of context from a message attempting to strengthen the position of the Nationalist Government, especially in enabling it to fill any vacuum left by the withdrawal of Japarese troops. 3 Under further examination by Democratic Senators, dedemeyer acknowledged that he had wanted some kind of arrangement between the Cominunists and Nationalists to rehabilitate the country. Although this was almost exactly the purpose which the administration gave as Marshall's mission, it would seem that the President's directive to Marshall went much further, especially in advocating the use of economic persuasion.

$$
\begin{aligned}
& { }^{1} \text { Ibid., pp. 2247-48. }{ }^{2} \text { Ibid., p. } 2249 . \\
& { }^{3} \text { Ibid., pp. 2297-98. }
\end{aligned}
$$


Did Russia favor a raporochement of the Nationalists and the Communists? jenator Bridges read part of a military intelligence report of 1945 which stated that there were reports of Russia wanting a coalition fovernment established in order that Morth China and Manchuria might eventually becone the exclusive terrain of the chinese Comunists, who could gain te upper hand. Considering the methods which might be used to bring the Kuomintang and the Commuists together after the war, tre report mentioned the Nationalist-sponsored General Assembly idea and the Communist-sponsored ldea of a coalition government, an idea which chiane had already rejected. The American military report concluded, however, that peace in the Far Fast depended on the unity of China to keep it out of Russian control. When previously questioned on this report in 1949, Dean Acheson had stated that this version had been written as a summary of the complete report by an officer who had worked on the original. The summary did not reflect the teror of the report as a whole and had been withdrawn by the military intelligence division. Hevertheless, in the meantime it had been circulated among Consressmen by Representative Judd. 1

According to Dean Acheson, wilitary men assented to Marshall's effort at mediation as the only hope for Nationalist control over North China and Marichuria. When the liationalists attempted to natntain and improve their 
position in Manchuria by force, the Arerican view was that they would fail. The only question was how disastrous the failure would be. To mitigate the effects of military defeat, the United States advised them not to take indefensible positions. 1

In July 1947 General Albert Wedemeyer was sent to China to advise the Nationalists. In a report to washington, he stressed the danger of Manchurla falling into Soviet hands, which would lead ultimately to a Communist-dominated China. He sugjested that China should promptiy request United Nations action to bring about a cessation of hostillties and the creation of a collective trusteeship composed of, perhaps, China, the Soviet Union, the United States, Great Britain, and France. ${ }^{2}$ Marshall pointed out that Vedemeyer proposed to place the Chinese problem before the United Nations; however, the United States was not convinced that United Nations jurisdiction extended to events within a particular country. Also, the proposal for a trusteeship would have ereatly embarrassed Chiang, who had stated many times that he would have nothing to do with any settlement which included the Russians or British as trustees. 3 In his testimony General Wedemeyer asserted that he had made these proposals to save as much as possible for China, since at the time of his report the United States had fust

$$
\begin{aligned}
& \text { I Ibid., p. 2029. }{ }^{\text {Ibid., pp. 2295-2308. }} \\
& { }^{{ }_{\text {Ibid., pp. }} 372 \text { and } 547 .}
\end{aligned}
$$


played down the capabilities of the Nationalists and thus had hurt them deeply. 1

Amexican Ald to the Nationalists

During the hearings there were many arguments on the question of aid to China. Acheson asserted that the United States sent considerable equipment to the Chinese Nationalists after the Japanese surrender; a large part of this consisted of ammition and arms left by the marines when they withdrew from the mainland. When Senator Hickenlooper sugeested that much of the equipment was useless for military operations, Acheson sald that this was not correct; nevertheless, he did admit that some of the planes turned over night have been cargo planes rather than military oneg. ${ }^{2}$ Wedemeyer suggested that after his mission he had advocated sendinf military and economic advisers to China, as well as moral and material aid. He did not believe, however, that the Nationalists lost China because of lack of equipnent. 3 Kefauver pointed out that the Wedeneyer paper had recominded that China inform the United llations of its request for increased inaterials and advisers. To the Senator this did not seem to be a direct recomendation for ald. ${ }^{4}$ Acheson had earlier said that althouith wedemeyer had not positively sugested sending ald, it was possible to read that into his report.
$I_{\text {New York pimes, June 12, } 1951 .}$
2 Military S1tuation in the Far Fast, p. 1887.
3Ibid., p. 2329. 4Ibid., pp. 2044-45. 
In speaking of assistance sent up to the time of the Marshall mission, Senator Knowland read a paraeraph written on October 11, 1945, which stipulated that no weapons were to be used in fighting a civil war. Acheson's angwer was that there was a strong bellef that the Nationalists were too weak to settle treir problens by force and that it was preferabie to negotiate. when questioned on a statement made by President Truman in December of 1946 that materlal Biven to China did not include war material, Acheson explained that thig was during a time when an embargo against sending war goods to China was in effect (from fugust 1946 to $\operatorname{may} 1947) .1$

Congress later appropriated $400,000,000$ for ilitary support. When Senator Bridges charged the State Department with opposing a larger appropriation by the Eightieth Congress, Marshall replied that the Administration had actually requested $\$ 575,000,0000^{2}$ The former secretary of State had earlier explained that much of the difficulty was in getting support from the various financial agencies with which he had to doal. As he recalled wedemeyor's estimate of about 10,000 officers and technicians needed to oversee and direct the operation in China, Marshall asserted that the Government could not have comitted itself to sending so many men. An indication of why it was impossible for the military to send a large force to the far last was that

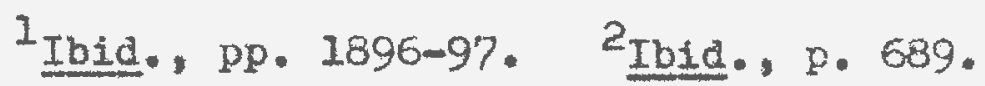


there were only one and a third divisions in the entire United states. 1

Several times Senator Hickenjooper brought up a statement by Marshall in 1947 that troops were sent to North China with orly two rounds of atunition per gun. Acheson replied that this statement indicated only that troops went to North China with little ammition, not tiret they had literally two rounds per gun. Even if more equipoent had been supplied, it is not certain that it would have been effectively used. One of the great weaknesses of the Chinese Nationalists was their complete ignorance of logistics and supply. According to General Collins, the United States had fully equipped ten Chinese divisions with Auericen equipment, all of which was lost. ${ }^{2}$

Toward the end of the hearings there were two opposing points of view presented on the adequacy of Afierican aid in 1948. Vice Admiral Badger, Naval Comander in the Far Dast after World War II, asserted that the Iruman adrinistration's efforts to aid China were haphazard, although generous. Refusing to accuse any specific person, he observed that what had earlier been an even chance of saving North China was lost in 1948 by a five-month delay in sending American arms. 3 He also proclaimed that the ten per cent of our equipment which did reach Chiang was of little

${ }^{1}$ Ibid., p. 465. ${ }^{2}$ Ibid., pp. 1888 and 1223.

3 New York Mimes, June 20, 1951. 
or no use. I In the same vein, General Wedemeyer testified that much of the equipment was of no more value than scrap iron because the Chinese had no use at that time for such things as road graders. 2

General Barr, head of our military mission to China in 1948, refuted Badger. Alleging that no amount of weapons could have saved the Chinese Commander, he believed that the Nationalist Government lost to the Commists because of its own ineptitude and corruption. The National1sts had exagcerated the ineffectiveness of weapons sent them, while missing parts were quickly replaced within two or three days. General Barr even accused Badger of contributing to the delay in shipping arms by falling to make requisitions. What arms the Nationalists did receive, they forfeited whenever they lost a battle, in the end leaving the Communists with a creater supply of American-made weapons than they themselves had. 3

China white Paper

When it became evident in 1949 that the Nationalists were golng to lose Chira, the Department of state prepared a paper explaining the situation, known as the China white Paper. 4 Acheson testified that he recommended the

${ }^{1}$ Ibid., June 21, 1951.

2 Military situation in the Far East, p. 2330.

3illiam S. White, "General Barr Defends U.S. China Folicy," New York Times, June 23, 1951.

3573, ${ }^{4}$ United States Relations with China, Fublication 
publication of this paper to let the kmerican poople know the facts. In this way they would not be so thoroughly shocked should the Nationalist Government fall. The necessity of preparing the public for this possibility outweighed any harm which might result for the lationalists if their weaknesses were revealed. Acheson pointed out that Chians had already been driven out of Northern China to Canton, which was also about to fall; consequently, publication of the White Paper could no longer have had a great effect on Chiang's fate. ${ }^{1}$

Forner Secretary of Defense Louis Johnson testified that he had argued in vain against the issuance of the report, since it seened to be a deliberate effort by Acheson to destroy the Nationalist regime. He also asserted that the paper had originally contained military inaccuracies, later corrected, and other shortcomings which remained in the paper. He asked what the purpose of tie paper was if not to destroy the Nationalist Government. ${ }^{2}$ Acheson maintained, however, that nothing short of unllmited American economic and military aid, including the use of our own troops, could have maintained the Nationalists in South China in 1949. In a letter of that year the secretary of State had asserted that this country had tried to influence the forces bringing the Comunists to power, but could not do so. He denied Senator Knowland's accusation that this

$$
\begin{aligned}
& \text { I Pilitary stuation in the Far East, pp. 1769-70. } \text { Ibid., p. 1867. } \\
& { }^{2} \text {. }
\end{aligned}
$$


was a defeatist attitude compared with our stand in Greece, for the circumstances in China were quite difierent. I

In reporting, the discusaion on the "urina "hite Paper," James Reston noted that the outcry which followed its publication lod ug to maintain relations with the Formosan Government and to consider sending a mjlitary mission to it. 2 Nevertheless, when the "dust settled" in China in 1949, Conmurists vere in power and the scene was set for conflict in the nearby iorean perinsula. 3

From the discussions on China in the hearings, the witer of this paper concludes that it was easy enourh for the Republicans to point out in retrospect supposed inaciequacies in the administration's policies. At the end of Vorld Var II, the kmerican people were in ro mood to ecrd more troojs to China. If, as larshall had sugersted, Chiang had initiated reforms, wao pse-tune's procram of land reforms would not have :on him such powernl support from the peasants. her the cabinet decided to send riarshall to

\section{Ibid., p. 1803. In his testimony larshall agreed} with Acheson on the difficulty of supporting chiang (ibid., p. 487). Wedsmeysr testified that the Nationalists could have held the Yanstze wit? broomsticks if the had had more spirit and less corruption, althoueh he complained that our lack of moral support and our overemphasis on lis wealness harmed chiang (ibid., pp. 2327-28).

\section{2iew York ilimes, June 5, 1951.}

3 Acheson explained his use in 1949 of the "dust seitling" term as reaning that he could not see what the outcome in China would be until the situation hac become clear (ilitary Situation in tie par ast, 0.1726 ). 
conciliate the warring factions in China, it was because there seenea no other alternative to those of complete withdrawal or all-out help for a full-scale war.

Few saw the importance of the Communist Chinese at the end of the war. Indeed, republicans could have attacked hedemeyer or Hurley, who had no efiective solution in 1946, although this yould not have lad the impact on the public which criticizing the State Department did. In short, post-war china was an area where neither the inilitary nor the civilian could formulate a policy which would work to our advantage, because they could not work togeter with the knowledge that the Anerican people would back any decision, whatever it might be. 


\section{CHAITER III}

\section{THE KOREAN WAR}

Fostwar Korea

After World Har II both the Republic of Korea, established in the South under the sponsorship of the United Nations, and the Democratic Feople's Republic of Korea in the North claimed to be the sovereign Eovernment of all of Korea. At a conference in 1945 a four-power international trusteeship was seen as a solution to the problem of Korea. The joint Commission established in 1946 to set up a government could find no way to operate, since the Russians would not agree to the full democracy advocated by the Americans. When no way could be found out of the ensuing impasse, the United States took the question of Korean independence to the Inited Nations. The Soviet Union proposed the simultaneous withdrawal of military forces of the occupying powers. This idea was opposed by the United States, which knew that the Russians had formed a solidly Communt government and army in North Korea. The General Assembly rejected the soviet proposal, but passed a resolution authorizing a Commission on Korea to use its good offices to bring about unification of the country and an integration of Korean forces. However, when the Commission 
decided to contact leading persons in liorth horea to try to effectuate a settlement, it was unsuccessful, and in the South shgman hee was unwiling that the United Nations broup make subjestions on the development of a more representetive government. 1

The inited Nations requested Americans and Iussians to evacuate their troops from Korea. The hrericans arreed to do so. The Joint Chiefs of staff Lelieved that the troops were needed elsewherc, ${ }^{2}$ and some officers, includins General Facirthur, did not consider the situation in Korea particularly threatening at this time.3 Ey renuing

I Ieland Goodrich, Korea: A Study of U. S. Policy in the United Nations, Council on Foreign Relations, New York, 1956, pp. 72-76.

2 Military Situation in the Far East, p. 1811. Testimony of san icheson. reorge farshall testified that the Joint Chiefs of stafi found it difficult to fully guard the airstrips in Alaska, while the U. S. occupation force in Japan was at only sixty per cent of strength (ibid., p. 382).

${ }^{3}$ Ib1d. , pp. 2167-68. Some wamings were Given, nevertheless, of the danger in Korea. Accoraing to Sen. Harry F. Byrd, It. Gen. John Hodges, commander of tre occupation forces, had declared before the Armed Services Comitiee in February 1947 that under conditions existing at the time the Jorth Koreans would dominate South Koreans if the U. $S$. troops were to witharaw (ibil., p. 2008). After his 1947 trip to China, General hedemeyer was irstructed to proceed to korea and to report on conditions there. He recomended that the United States organize arie equip a South Korear. scout force to resist any attack from the North, for unless Anerica bave assistance, a North Korean occupetion of the whole peninsula could be predicted (ibia., $\%$. 1988). Tris part of the 1947 Vedeneyer report was rot made public, according to Secretary of state ficheson, because certain statements therein micht have caused a break of harmony in certain quarters (ibid., p. 1987). Acheson maintained, however, that General dedemeyer had agreed to the decision to withdraw on the basis of a need for economy. 
our army we could hope to prevent a strucile in the peninsula, which was strategically a poor place to fight. ${ }^{1}$ Also, pressure for a speedy withdrawal was exerted by South Korea. 2

The United Tations Commiscion reported an evacuation of all United states forces by July 27, 1949, except for a lilitary Advisory Group of about five hundred men and officers. The Comais:ion was unable to verify whether the Soviet Union had carried out its anrounced witharawal by the end of 1948. To lessen the possibility of military conflict between the two sections of the country, the United rations planned the use of trained observers alono the frontier between the liorth and tie jouth. 3

The United states was more interested in strengthening South Korea economically than militarily. According to General Machrthur, American troops had left suficient equipment behind wo stop Iorth rorean security forces; it was not, however, suficient to stop a well-equipped attacking force. 4 In January 1950 our military mission sigred an ajreement with Korea for almost $\$ 11,000,000$ worth of nilitary goods, and at the time of the June invasion a large part of the equipment was being shipped. Still, since the equiphent had to come from new jrocurement

I Ibid., p. 753, General Bradley's testimony.

'Itid., p. 243, Machrthur's testinony.

${ }^{3}$ Goodrich, pp. $78-79$.

${ }^{4}$ Military Situation in the Far Fast, p. 243. 
or from partly depleted stocks, there was some difficulty in getting the proeram inder way, and neitiver of these sources could have been satisfactorily tapped in the ninety days between the working out of the program in March and the June invasion. 1

The United States had been criticized both for not making clear what it would do if an attack from iforth Korea occurred and also for its failure to give adequate rilitary support to the rresident of South horea. ${ }^{2}$ secretary of State Dear fcheson was accused of revealing the indecision of the United states in reference to the protection of Korea in a speech before the rational Fress Club on January 12, 1950. Mir. Acheson emphasized that in this speech he had been speaking mainly of areas where United States troops were stationed and which they had to defend. In referring to other rejions of the Pacific, he had stated that no one could buarantee tiese areas arainst military attack, but that tive initial reliance for defence wust rest on the indicenous people. These areas could then count on "the commitments of the entire civilized world under the charter of the United liations which so far has not proved a weak reed

${ }^{I_{\text {IDid. }}}$ pp. 1337 ard $1993-34$, Acheson's testimony.
${ }^{2}$ In view of the poor trainiris and morale of the south Koreans, it remained questionale from evidence presented in the hesrin ${ }_{0,3} 3$ whether wore aid would rave telped the Korears (ibid., pp. 243, 2114-15, 3334-85). Senator Greane pointed to the fear of some authorities that President ?hee would use armaments to amount an attack against Forth Korea as a reason for not tendering more aid (1bid., p. 2114). 
to lean on by any people who are determined to protect

their independence against outside aggression." 1

Yean Acheson quoted parts of a speach by John Foster Dulles, then Consultant to the secretary of state, before the National Assembly of the Republic of Korea on June 19, 1950, to show that we never adopted a policy of abandoning Korea. After telling the Koreans that "the American people Eive you their support, both moral and material, consistent with your own respect and primary dependence upon your own efforts," Dulles emphasized that the United Vations "requires all nations to refrain from any threat or use of force against your territorial integrity or political independence." 2 It is probable, however, that forth Koreans were already preparing to attack and that this speech came too late to be a deterrent factor.

Invasion of South Korea

It was five days after Dulles' speech that the North Koreans attacked. What evidence had there been that this invasion would occur? The Far liastern Comand, the Central

IIbid., pp. 1740-41 and 1811-12. In their book The General and the President and the Future of American Foreign Policy (New York: Farrar, Straus, and Young, 1951) p. IOI, Richard $\mathrm{H}$. Rovere and Arthur Schlesinger, Jr. express the opinion that Acheson's statements were foolish in inviting asgression. On the other hand, valter Millis thinks that icheson could hardly have ststed otherwise, since American troops had beer withdrawn from Korea (Arms and the State: Civil-Military ilements in National Folicy. New York: Council on Foreign Felations, 1956$), p .260$. 2 Military Situation in tie Tar East, pp. 2020-22. 
Intelligence $A_{E}$ ency, and other roups had reported the possibility of an offensive, but one did not seem imment. The administration believed that since the Communists had far from exhausted the possibilities of guerilla and psychological warfare, political pressure, and intiraidation as means of obtaining their objectives, they would probably continue these nethods instead of undertaking overt military action. Secretary Acheson quoted a report of March 10, 1950, from General MacArthur. According to this report, the Soviet Union would probably attempt to take over parts of Southoast Asia which were less well guarded before moving against South Korea. The report did state, however, that if checked in these areas, Russia might divert a large shae of its attention to South Korea and might even invade this territory. When Senator Bridges claimed that this was a definite warning of the coming attack, Acheson responded that the Far East Comand had not believed the statement and had reported that there would be no civil war in Korea that summer. Also, previous unfulfilled reports of invasion had been received as early as October 1949. I

About 9:30 P.M. on June 24 Ambassador John Muccio informed ashington that North Korean forces had invaded South Korea. On the morning of the twonty-fifth, Ambassador to the United Nations Ernest Gross requested a meeting of the Security Council. With Russia absent in protest

I Ibid., pp. 230-31. 
over United Nations refusal to recognize a representative of Communist China, the Council adopted a resolution declaring that is breach of the peace had occurred and calling for the North Koreans to cease hostilities. ${ }^{l}$ the resolution also called on all members to render every assistance to the Inited Nati ns and to refrain from assisting the North Koreans. 2

Some Senators tried to determine whether Fresident Truman had made the decision to commit. ground troops to enter the Korean fighting only after careful deliberations with his advisers. Testinong showed that the Becretary of State, Secretary of Defense, the Joint Chiefs of Staff, and others were prosent at the Blair House meeting when decisions on how to meet the threat in Yorea were made. 3 is Secretary of Defense Johnson testified, the milltary did not recommend going into Korea, but neither did any of the officials opyose doing so when they had the chance. 4 Neither did members of Consress when they knew what American action would be.

At a BIair House meeting on June 26 it was decided to move the Seventh ileet to he frormosa Straits, to use raval and air forces to protect the evacuation of American nationals, and to furnish arms to the Republic of Korea. ire

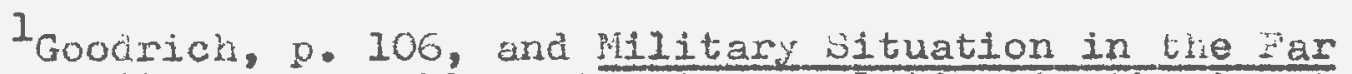
Sast, p. 1211. Mershali read this resolution to the Benators. I Ibid., p. 361. 3Ibid., pp. 2572-76. ${ }^{4}$ Ibid., p. 2585; cf. Bradley's testinony, pp. 933-34. 
next day President Truman reported to Congress that following the Security Council call upon members to render every assistance in stopping the aggression, he had ordered United States air and sea units to give Korean troops cover and support. ${ }^{I}$ on the twenty-ninth of June authorization was given to extend operations to North Korea, but only if this were necessary to complete the mission of clearing the South of lorth Koreans and of retaining a port and air. base in the ares of Pusan. 2

General MacArthur informed the Joint Chiefs of Staff of the confusion of the South Korean Army, which he observed on a reconnaissance of the Korean battle area. Much equipment had been abandoned or lost. It was possible that the North Koreans could break through. In fact, the holding of the fan River line could be assured only by using ground troops. 3 Therefore, General MacArthur advised the

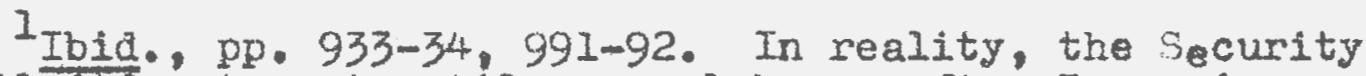
Council did not meet until several hours after Truman's announcenent, and it was still later when it adopted a U.S. draft resolution recommending assistance.

2Ibid., p. 536, Marshall's testimony; also, p. 934, Bradley's testimony.

3 Ibia., p. 1112 and 235. General Hedemeyer testified that he would not have sent ground troops into Korea; nevertheless, he is careful to point out that he misht not be able to pass a competent judgment on this question, as he had not been in Korea and did not know all the detalls (ibid., pp. 2307-08). On the other hand, he maintained that the government was "absolutely correct in taking affirmative steps against the advance of communism. we had to do It some place and the time was already overdue,. . . (ibid. p. 2315)." Admiral Sheman also stated that he thought the decision to comit ground troops was sound, al uhouth he had had apprehensions at the time (ibia., p. 1651). 
Joint Chiefs, if so authorized, that he intended to move an American regimental combat team to the combat area as the nucleus for a possible build up of two divisions from Japan. This would make an early offensive feasible in accordance with his mission of clearing South Korea of Northern troops. 1

\section{Collective Action in Korea}

on July 7 the action of sending ground troops into Korea was affirmed by the United Nations Security Council. It recomended that members of the United Nations make forces available to a unified comand under American direction to carry out the June 25 and 27 resolutions. MacArthur was designated as the military leader. Although his position was created by the world body, the appointee considered his connection with the United Nations as largely nominal, sirce the entire control of his command came from the Chiefs of Staff and even his reports were sent to the State and Defense Departments before being forwarded to the United Nations. According to MacArthur, he had no direct connection with the United Nations. 2

In outlining milltary strategy at the beginning of the Korean har, Machrthur mentioned that it was problematical at first whether any remnants of the South Korean Army could be saved. At the time of the invasion, the

$$
\begin{aligned}
& I_{\text {Ibid., p. 1112, Bradley's testimony. }} \\
& 2_{\text {Ibid., p. 10. }}
\end{aligned}
$$


Joint Chiefs had underestimated the number, equipment, and ability of the North Koreans. ${ }^{1}$ Whlle South Koreans were burdened because of logistic mistakes in the arrangement of supplies and equiphent close to the thirty-eighth parallel, the invaders had been trained and disciplined well. 2 To ald the South Koreans, America could contribute imsediately only the four divisions of the Eighth Army in Japan. Macirthur believed these troops to be as good as any without combat experience, in spite of some defects in organization, which could be blamed on efforts at economy. 3

Although many problems were encountered in establishing a beachhead near Pusan, MacArthur managed to put in two battalions of infantry. These troops put up a "magnificent resistance" before being destroyed. After an amphibious landing at Inchon surprised the North Koreans on September 15, the United Nations forces were able to advance. ${ }^{4}$ A few weeks later they neared the thirty-eighth parallel, and the question of crossing into North Korea confronted the Allied leaders.

General Macirthur submitted his plan for operations north of the parallel. The Eighth Army was to attack along the western coastal area while the United States Tenth Corps at Wonsan was to nake an amphibious landing on the

I Ibia., p. 948. Bradley's testimony.

'Ibid., pp. 230-31. 3 Ibie., p. 237.

${ }^{4}$ Ibid., pp. 231-32. The Inchon Ianding was MacArthur's 1dea. Louis Johnson testified that Collins had opposed the idea, and Admiral sherman had had reservations. (ibid., p. 2661 ). 
eastern coast of North Korea. ${ }^{1}$ on September 29 the Joint Chief's approved PlacArthur's plan, includins, however, some restrictions on just how violent the attack aingt North Korea should be. ${ }^{2}$ Because of serious political implications of such an action, no all-out bomb attack, nor any attack against Pyongyane and similar targets, should be authorized without prior clearance with the Joint Chiefs of Staff. According to General Colling, this was because we wished to avold bonbing cities which would later have to be rebulit. 3 wad also assured other countries that in carrying out military efforts nortb of the parallel, caution would be taken not to do anything likeiy to extend the conflict. For this reason orders had boen sent that United liations troops were not to cross the Manchurian border under any circuratances and that no non-Korean forces should be used in the provinces bordering the Soviet Union and Manchuria. 4

On October 7, United Nations support of the crossing of the parallel was obtained when Great Britain introduced a resolution that the forces in Korea should proceed with the pacification and unificetion of all of Korea. 5 The JCS were then authorized to direct General MacArthur to

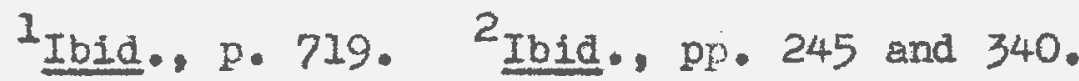

3Ibld., pp. $1362-63$.

${ }^{4}$ Ibid., p. 1230, testimony of General Collins.

I Ibid., pp. 26,98 and 3171. According to the New York Times of October 8, 1950, troops crossed the parallel at 
plan for the possible occupation of North Korea, but to execute such plans only with the approval of the Prosidert. In the event of occupation of North Korea by Soviet or Chinese Communist forces, General MacAxthur should undertake no ground operations north of the parallel; however, air and naval operations should not be discontinued. Final decisions would have to be made in view of possible actions by the Soviet Union and the Chinese Communists. If Chinese troops came south of the parallel, the United States would not permit itself to become enfaged in a general war with Communist China. General Macirthur was authorized to continue rilitary action as lone as there was a reasonable chance of successful resiatance. 1

On October 24, General Nackrthur informed the field commanders that he was lifting restrictions on movement of the forces in lorth Korea and was authorizing them to capture all of the territory. He cautioned, nevertheless, that lnited Nations forces other than 5outh Korean should

3:14 A.M. LUT on October 7. This was before the General Assembly had approved the resolution. MacArthur stated that on tise basis of tris resolution he had ample justification for crossing the border between Forth and South Korea (ibid., p. 245; cf. General Bradley's testimony, ibid., p. 987$)$.

I Ibid., p. 718. Read by Senator Morse from the document "Joint Chiefs of Staff Report for Senate Comittees on Korean Operations." According to Millis, p. 27, this directive placed responsibility for decisions on Machrthur which should have been made in washington. If Hashington was ready to send troops into North Korea, it should have been prepared to meet possible consequences. And yet orders failed to provide specifically for the possibility of Chinese intervention. 
De withdrawr as soon as feasible and be supplanted by Yorean units. On the same day the Joint Chiefs of Staff advised the - ar ast Commander of tre inconsistency of this order with their policy of not allowing nor-Koreans in the area close to the Yalu. is General Collins pointed out, there ha been plenty of time for lacArthur to wire and inform lashingtor of his opinion on the disposition of troons before siving these orders. ${ }^{1}$

\section{The Comunist Chinese Invasion}

Iid General Machrthur have adequate varning of the Chinese invasion into lorth Korea? Why did he, during a Iull in the firhting, launch an offensive on November 24 which was to end the war, but which instead led to mass Chinese intervention? At a conference on yake Island in mid-October between President Truman and the General, the Commander-in-Chief had requested ManArthur's opinion of the possibility of Chinese or Soviet intervention. His answer had been that they might be able to send in fifty or sixty thousand Chinese troops, but without ain force support "there would be the greatest slaughter" if they tried to irive south to Yyongyang. Ile could not picture Russian planes effectively working with chinese ground troops. 2

I Military Situation in the Far ast, p. 1240. When questioned by Morse on whether the JCs were in a good position to pass judgment on military tactics with the aid of teriain maps, Collins enswered in the affirmative (ibid., pp. 1300 ard $1312-13$ ). 
During tie hearins Wacicthur spoke of some knowledpe of Chirese power wen je stated that, "the chinece Comunists fad collected lare forces along the ralu itver. Hy own reconnaissance, fou understard was limited entirely to Korea; but tie ceneral iniormation wich was avilable, from Chine and other places, indicated larse accumulations of troops."I He had certainly known of a chinese troop movenent up the coast of China in the direction of Korea in September. From about the twenty-seventh of that month more ard more evidence of possible Communist intervantion came in. Towever, some of the reports cane frin Chinese Nationalist sources, previously mistaken in tieir estirate. 2 Other nations gave warnins. On October 3 thr Chinese Comunist Foreign Minister informed the Indian Ambassador at teiping of Chna's threat to send troops into Korea if tne United Nations forces croseca the parallel. Nievertieless, the tireatened action was not io be carriej out if only south horean troops crossed irto : warning could have ell been viewd with acepticism by American officials. Pirst, the Communists mi int have been intefested primarily in influencing the United Nations, for on

\section{1 ivilitary uituation in the far iast, p. 13. while} speaking of the difilculty of knowing in ashington what happened brtween iovember 6 and the full invasion of the twenty-sixth, General Bradley said that much of the intelligence lacking to the JCS should have cone from Machrtaur's own field command. Liven though the ground was beavily wooked and troops were difficult to see, a concertration of forces on the right flank of the ishth army should have veen picked up by ain and naval reconnaissance (ibid... 1036)

Ibic., p. 1234; testimony of General sollins. 
October 4 the Folitical Jomittee of the General issembly was to vote on a resolution calling for steps to ensure conditions of stability throu hout rorea. 1 isond, the Indian fubissador had before warned of attacks which had iever materialized. 2

Although the first Chirese prisoner was captured on vctober 26, as late as November 4 Mackrtiur reported that while Chirese intervention was a distinct possioility, there was not suficient evidence to be positive of it. Lowever, the very next day the coneral submited a special report to the trited ations reporting his forces "in hoswije cortact with Chinese Communt military units." 3 on November 24, when a mass novement across the parallel occurro, it wa still tie view in washingtor that tre chinese objective was to ortain a lniled letions withdrawa by intinidation and aiplomatic means, and that only if these failed would there be increasing intervention. ${ }^{4}$ During the hearings, icheson spoke of the lack of real advantage to China in becoming involved and tie loss she would sustain in her international posttion in doing so as reasons why it was thoupht the Chinese Communists would not intervene. 5

\section{I id., p. 1333.}

${ }^{2}$ Rovere and schlesiliter, p. 140. During the hearings, Hecirthur claimed th $t$ be had received no official notification of this warning by the chinese, that ali he knew was Eleaned rron readin the rewspapers (M1litary bituation in the iar Liast, p. 109 ).

$$
\begin{aligned}
& 3_{\text {Ibid., p. 1333. }} \text { Ibid., pp. } 1332-35 ._{\text {Ibid., p. } 2101 .}
\end{aligned}
$$


The authors of the General and the fresident are quite severe on General MacArthur for not making better use of the intelligence he had. After showing the number of Chinese encountered in late Octoher and early Noverber, the authors accused the general of making light of the Chinese intervention, even reporting from Tokjo on the day oight Chinese divisions were identified in Korea that there was insufficient evidence to accept the invasion as a fact. 1 According to the authors, it was still a puzzle after the hearings just why General MacArthur launched an offensive on November 24 with forces he knew to be inferior in numbers to the Communists. 2 Perhaps he believed that the Chinese would back down if he were firm, and, too, he might have considered a holding back under the circumstances as a sign of weakness. 3

In supporting his advance at the end of November, MacArthur explained:

Now what we actually did was to move forward to ascertain in strength of the enemy's forces. When we moved forward, I had elready prepared, and the troops had in their hands, the order for retreat if we found the enemy in force. What we did was really a reconnalssance in force. It was the only way we had to find out what the enemy had and what his intentions were. 4

This assertion conflicts with Macarthur's communiqué of Movember 24 describing the coming campaign and ending with the

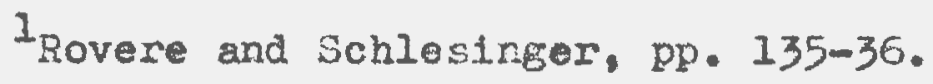

Ibia., p. 152. ${ }^{3}$ Ibid., p. 140.

4 Military Situation in the Far East, pp. 20-21. 
sentence: "If successful, this should for all practical purposes end the war. . ." During the hearings, Collins declared that Macirthur was "bert upon tho druction of the North Korean forces." I

Had the Jar zast commander used poor judgment in the deployment of his trops in liovember? rackrthur spoke of complete coordination of the wighth army and the Xth Corps under his airection. Nevertheless, the Joint Chiefs had evidently been somewhat worried about the disposition of the forces betore the chinese invasion ard had asked Machrthur poittely if he reeded aditional arectives. Won he answercd in the negative, ashington did not pursue the matter, for stratesy was consicered the responsibility of a theater comander.2 hen after the first chinese blows, the far sast comander supported the separation of the xth Corps from the ighth Amy with the asiertion that the terrain was too ruked for the enemy to be able to take advantaye of ary delay in coordinatire activities, the JCS demanded to extrication of tive advarced units of tre Marines. The Far ast commancer soon afterwarcs told collins

$$
\begin{aligned}
& { }_{\text {Ibid., p. 1369. }} \\
& 2_{\text {Ibid.. p. 246. From hindsight, Bracley would heve }}
\end{aligned}
$$
deployed troops a little disierentiy, although, he admitted Hachrthur might have had some additional information which made him deploy the troops as he did (ibid., p. 972). If facirthur had had this inionation, it is surprising he had not mentioned it. As it was, he stated during the hearings that "the disposition of those troops, in my opinion, could not have been improved upon, had I known the Chinese were going to attack (ibid., p. 19)." 
that if the restrictions on air reconnaisisance were removed, maximura use made of the Chinese Nationalists, Manchuria bombarded, and a naval blockade mounted, he would be willine to recombine the Xth Corps with the righth Army to hold a line across Korea. Phis was the same line which he had considered impractical on November 30 when questioned by his superiors. ${ }^{1}$

\section{An Entirely Now War}

When it became obvious that the Chinese vere invading in large numbers and had initiated "an entirezy now war," as the leader of the United liations forces called it, what courses were open to the adriristration? Before the congressional comittees General MacArthur stated that China should have been warned "that if she did not within a reasonable time discuss a cease-fire order,. . . the entire force of the United Nations would be utilized to brine to an end the predatory attack of her forces on ours." 2 In spite of this declaration, Collins could not recall the Far East comander ever makine a recommendation to the Joint Chiefs that an ultinatum be issued to the chinese. 3 on the other hand, they gave him no new directive to replace the one of clearing North korea of enemy troops. 4

$$
\begin{aligned}
& 1_{\text {Mi11is, pp. 296-97. }} \\
& 2 \text { Military Situation in the Far East, pp. 29-30. } \\
& \text { 3 Ibid., p. 1261. }{ }^{4} \text { Ibid., p. } 30 .
\end{aligned}
$$




\section{1}

Nevertheless, the general did have his own program to solve the Forean problem. His reports to washington at this time were very pessimistic. On December 3 he described his army as "facing the entire Chinese nation in an undeclared war." "Unless some positive and immediate action is taken," he continued, "hope for success cannot be justified and steady attrition leading to final destruction can reasonably be contemplated." I In light of this report, the Frewant sent General Collins to Korea to view the situation. The Far bast commander explained to the Amn Chief of staff three courses of action which he saw as possible. One of these was to continue the fight with the existing limitations on action (no air attacks on Manchurian bases, no naval blockade oi China, no use of Nationalist Chinese troops, and no great increase in the number of United Nations troops in Korea). By doing this, however, the Unlted Nations would be forced out of Korea. A second choice could be to continue the fight without the above restrictions. This was the course of action preferred by the United Nations' commander. An armistice in which the chinese Comunists agreed to remain north of the thirty-eighth parallel was the third possible action. ${ }^{2}$

\section{In the following month the laen of evacuation was} considered by the military in washington. However, in view of pessimistic reports MacArthur was sending the JCS there seems little basis for his later statement that "the Joint Chiefs of Stafi were not sure could stick in Korea. It was my opinion that we could." Quoted by Sen. Smith (ibid., p. 1103 .

$$
2 \text { Truman, p. } 415 \text {. }
$$


Fresident Truman was concerned at the distance between the administration's policy : nd these ideas advocated by the United Nations' commander. ${ }^{1}$ mhis difference in outlook becane more obvious in tie exchanges which occurred between okyo and deshirgton in December and January. In mid-December the United States supportea a resolution introduced in the United Nations by India which advocated setting up a three-tian committe to explore the busis for a ceasefire. The Communists kept advancine, however, and on December 29 the Joint chiefs of Stafi sent Machrthur a rew directive, thus replacing his basic orders of september 15. After mentioning that Chinese Communist forces appeared capabie of forcing evacuation and after stressing the impossibility of providine more troops, the Jofnt Chiefs told Macarthux that his basic directive was henceforth to be "to defend in successive positions, subject to safety of your troops as your primary consideration, inflicting as much damage to hostile forces in Korea as possible." The directive then went on to state that he was to "make advanced determination of [the] last reasonable opportunity for orderly evacuation." 2

In his reply of December 30 General Machrthur held that a forced evecuation of Korea would have an adverse effect upon the peoples of Asia and that the eventual results of such action would call for even greater forces in the far 
Hast. He did rot want to evacuato his troops, but intimated that he wifht we forced to do so if he were not Eiven reinforcements and if one or wore of the restrictions piaced on hin wer not removed.

On January 9 the Joint Chiefs of Staff informed the Eereral that these restrictions, amounting to retaliatory weasures which might enlarge the conilict, could not be removed. ie sholild, therefore, defend tie peninsula in successive positions, inflicting maximum damages on the enemy He should continually keep in mind the safety of his troops and his hasic mission of protecting Japan. Only if it became evident that evacuation was easential to avoid severe losses of wen and material was be to withdraw from the peninsula. 1

On January 10 General HacArthur reported tie military advisability of withdrawing from Korea, although he mentioned that poitical considerations misht ake it impractical to do so. 2 Two days later Tokyo headquarters recelved a report from the JCS which General Machrthur interpreted as a possible change in American policy and an agreement in

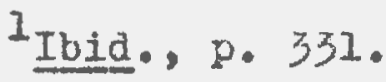

$2_{\text {liis report stated that "in the absence of overriding }}$ political considerations . . the command should be witharawn from the peninsula just as rapidly as it is feasible tactically to 10 so. If, on the other hand, the priarary political icterests of the United States in the Far Last lies in holding a position in Korea and thus pinning down a large segment of the Chinese aliftary potential, the military course is inplicit in political policy and we show?d be prepared to accept ang attendant hazard to Japari"s sechrity and whatever casualties result. (ibid., p. 906)." 
principle to h1s proposals on action afairst the Chinese. Faced with the possibility of evacuation, the Joint Chiefs had made several studies and had finally dram up a list of sixteen actiong which might be taken to prevent the loss of Horea. Included in tre sixteen were the four sugcestions made by General Machrthur to Collins in Korea and again in the December 30 report to the Joint Chiefs. Unfortunately, the copy of the study sent to Machrthur did not indicate how it had been devised and started off with the statement "It has been tentatively arreed. . " I Although Bradiey sugcested that the sixteen steps were to be taken in case of all-out war with China, ${ }^{2}$ General Marshall indicated the opposite, evacuation from Korea, would call up these points for consideration. In adaition, a low level of morale amone the troops might necessitate the use of some of the actions, even if the situation in Korea were stabilized. 3 Pointing to the ambiguity contained in the stated purpose of the study, General Sherman characterized IfacArthur's interpretation that the Joint Chiefs favored these measures as not unreasonable. However, any doubt in the mind of the Far East comander should have been removed shortly after this when Generals loyt Vandenberg and Collins went to Korea. Collins tried to make clear to General MacArthur that the proposals were only part of a study, a

IIbid., p. 106. During the hearings MacArthur admitted that the paper had been sent to him only for his information.

$$
{ }^{2} \text { Ibid., p. } 736.3_{\text {IbId., p. } 334 .}
$$




\section{5}

name which MacArthur himself had used when referring to them in the hearing. 1

On January 13 President Truman sent a message to pokyo outiluine important political factors purposely omitted from the message of the previous day. He wrote of the ni:cessity for prudence in taking any actions which might alienate tha allies or exterd the area of hostilities. After writing of the deterrent to communism which a successful resistance in Korea would be, he maintained that although it might be necessary to withdraw fron Korean soil, it should be made clear that the course was being forced on us by military necessity and that we planned to rectify the situation." Understandably, neither MacArthur nor the administration wanted to be blamed for a withdrawal from the peninsula.

Fortunately, evacuation was soon deemed unnecessary. According to Collins, both he and hacArthur reviewed the situation and found United Nations forces capable of maintaining their position. On January 17 General Collins found the Eicth Army in good shape with its morale improving. 3 At a meeting on this same day tre National security Council agreed to the inadvisability of putting all the recomendations into effect since conditions in Korea had changed in the preceding week. The military situation was

$1_{\text {Ibid., pp. } 737,1220 \text {, and } 2111 .}$

Ibid., p. 503. General Marshall read a paraphrase of the messare.

Ibid., p. 324; testinony of General Marshall. 
beginning to improve, and during the latter half of January the enemy was on the defensive. When during February and March United Nations forces maintained the initiative, it was fortunately unnecessary to carry out any of the courses of action outlined in the Joint Chiefs' study. 1 As the military situation improved, the administration conferred with other fovernments to establish a basis for a possible cease-fire. Whout clearance from Washingtor, eneral MacArthur issued a statement on March 24 offering to confer with the enemy and inferring that the war might be enlarged if the Communists did not come to terms. When other statements of the general continued to reveal his disagreement with the administration on military and political strategy, President Truman decided to remove him from his commands in the par rast. 
CHATMER IV

TIIE: RECAII

Macirthur's Peturn to the United States

When in April 1951 Douglas MacArthur returned to the United States, Americans accorded him an acclain greater than any citizen had recelved since Iindbergh's flight across the Atlantic and subsequent reception. A storm of protest arainst the removal arose imedietely. During the Senate hearings in May and June, senators questioned administrative officials to pinpoint reasons for the President's action. Pepublican Senators tried to prove that Truman had acted precipitously and because of personal prejudice. Nevertheless, from testimony of both military and political officers, it soon became clear that all had agreed to the wiscom of mruman's move.

On April 6, 1951, the President had callec for a meetine to aiscuss a letter from MacArthur to pepublican Conressman Joseph inartin. The chief executive had already rade up his mind to dismiss the general, but wanted the opinions of his chief advisers before making any announcenent. Present at the meeting were Dean Acheson, George Marshall, Omar Rrgaley, and Averell Harriman. The decision 


\section{8}

to relieve the compander was unanimous. In fact, Averell Harriman thought that ho should have been relieved two years earlier, an opinion shared by Marshall after he had read Mackrthur's commications with washington. ${ }^{1}$ when the Joint Chiefs of Staff were asked if it was militarily feasible to leave the general in charge of the occupation of Japan while removing him from his Korean post, they asfreed that it was not. 2

News of the dismissal reached MacArthur over a commercial broadcast, taking him by surprise. Secretary of the Army Prank Pace, who was then in Korea, was to have delivered the Frosident's messaje to the general. Because of the breakdown of a power unit in Iusan, Pace could not be reached. Hearing of a possible leak, administration officials then announced the dismissal. The action came as a surprise both to the American public and to the person nost involved. 3

Issues involved in dismissing General pacArthur were of the ereatest importance, ranging from the power of the Fresident as Commander in Chief, American security, the situation in Japan, reaction abroad, to the possibility of a public controversy in the United States. 4 In his testimony before the committees, General Bradiey pointed to

${ }^{1}$ Ibid., pp. 344-45. ${ }^{2}$ Ibid., pp. 345 and 740.

I Ibid., pp. 421 and 1773.

${ }^{4}$ Ibid., p. 1776; testimony of Marshall. 
three military reasons for which the Joint Chiefs believed MacArthur should be relieved. The first of these was that by public statements and official commications he had indicated a lack of sympathy with the decision to try to limit the war to Korea. This would make it more difficult. for him to carry out airectives. Second, he had failed to comply with a directive of December 6, 1950, to clear pol1cy statements with Washington before publishing them. Also, he had taken independent action in proposing to negotiate directly with the enemy and had made that proposal public even though he knew that the government was already considering negotiations. Third, the Joint Chiefs felt that the civilian authority of the country must control the military. 1

\section{Differing Views on Formosa}

Although his public anrouncements were the main reason for MacArthur's dismissal, his first rift with the administration came over an interpretation which the world put on a visit he made. After the June invasion from North Korea, the Soviet Union accused the United States of ageression and of designs on Formosa. In July MacArthur

IIb1d., pp. 878-79. Marshall also emphasized the responsibility of the JCS, the Secretary of Defense, and the President, who have an overall view of the objectives of the nation, to determine where the main threat lies, where we must fight holding actions, and where we must gain time to grow stronger. He added, "What is new and what has brought about the necessity for General MacArthur's reroval is the wholly unprecedented situation of a local theater commander publicly expressing his displeasure at and his disagreement with the foreign and nilitary policy of the United States, (1bid., p. 325)." 
let washington know of his plan to inspect Formosa, now under his command. Because other countries might interpret this visit as a preparation to help the Fornosans in an attack against the mainland, the Joint Chiefs of staff suggested to the Far Hast comander that he might want to send a subordinate to view the situation on the island. I In spite of this suggestion, the general went mimself. His visit received much publicity in the world press and was interpreted as possibly foreshadowing a change in United states policy. In view of this, Louis Johnson dispatched a directive to MacArthur remindine him of the United states policy of preventina the Generalisaimo from attackine the mainland. Although the general answered that he understood and would be obedient to the directive, the administration sent Averell Harriman to the far East to ensure his compliance. After conferring with the general, Harrinan remained dubious of Macirthur's f'ull acceptance of adtinistrative policy. The general even advanced his readiness to deal with policy problems, but only if given further orders from the Fresident permitting nim to do so. ${ }^{2}$ Truman soon issued a statement that he and the reneral saw "eye to eye" on Formosa. 3 It was quickly seen that this was not so when on August 12 the Far Hast comiander issued a statenent attacking those who "invariably in the past have propagandized

Ibid., p. 173. 2Millis, pr. 268.-69.
3.rumen, p. 354.


a policy of lefeatism and appeasement in the Pacific" and who were now misrepresenting his trip to Formosa. Fe hoped the American people would not "be misled by sly insinuation, brash speculations, and bold misstatements inveriably attributed to anonymous sources."I Many saw this as an attack against the Truman samintration.

His disarreenent with the administration appeared acain in sugust in a messace he prepared for delivery to the Veterars of poreign vars. Allies in the united Nations were still nervous over the possibility that the Korean conflict mitit spread. Tils fear would certainly not be alleviated by Machrthur alleging, as he did in this messace, that there existed an island chair, supposedy including Formosa, from which "we can dominate with air power every Asiatic poit from Vladivostok to singapore. . ."2 The belligerent tenor of the speech surprised and disturbed the Fresident. He thus requested the general to withdraw it. Unfortunately, the office of the Far East Commander had already submitted a copy to the press wilch subsequently appeared in two popular magazines. 3

\section{The December 6 Directive}

No dissonance between Machrthur and the Fresident was discernible from August to November, during which time they

$$
\begin{aligned}
& I_{\text {Millis, p. } 270 .} \\
& \text { 2ilitary Situation in the Far iast, p. } 2002 . \\
& \text { 3 Ib1d., pp. } 1217 \text { and 2003. Testimony of General }
\end{aligned}
$$
Collins and Dean Acheson. 
met on the island of wate. However, after the massive Chinese Communist attack at the end of November, General MacArthur made soveral statements atterpting to justify his recent strategy. Arthur Krock of the New York Times had sent a telegram to Macarthur requesting his coment on statements by officials that he had refused to accept responsibility for the security of his command if any halt were nade short of the Yalu. Mac. rthur's rewarkable reply was, "There is no validity whatgoever to the anonyous gossip to which you refer." 1 Yet only six days previously the JCS had suggested limiting contact with the Chinese and the possibility of a neutral zone.

In an exchange with the editors of United States News and World Report, MacArtiur was asked, "Are the limiiations which prevent unlimited pursult of Chinese large forces and unlinited attack on their bases regarded by you as a handicap to elfective military operations?"

"An enormous handicap, without precedent in history," was MacArthur's frank answer. 2

These statements appeared in the press at a time when Frime Minister Attlee was in Washington speaking in favor of a limited war. MacArthur's statements calling for a more active campaign thus greatly embarrassed the administration. Consequently, on December 6, 1950, the Joint Chiefs issued a directive to all theater comanders

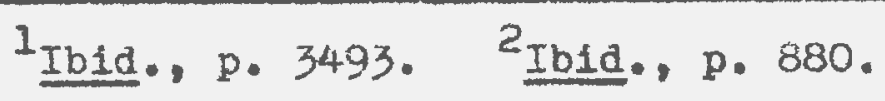


ordering them to exercise caution in their publio statements. They should clear any message conceming foreign polley with the Departwent of State and otatenents concerning military pollcy with the Department of Defense before releasing then. 1

When Genoral MacArthur polntedly subnitted his next routine announoement for epproval, Wabington informed him that such communiques need not be cleared, General Whitney later asserted that the December 6 directive was interpreted at Pax Bast headquarters as applying solely to formal public statements and not to communtqués, correspondence, and converation. ${ }^{2}$ It was not unt1l several months later that MacArthur actualiy released statements contraxy to adminietration policg. Meanwhile, he had been troing to change the policy of holding the line in Korea by stating in reports to the Joint chiefs that he might not bo able to whatand the Chinese hordes unless given permission to use greater fored agalnat thew. 3

\section{Difierences of Opinion on Military Matters}

General MacArthur declared in his testimony thet there never was a more subordinate solaier than himself. As Bradley would stregs, this was true in the militaxy aphere. However, the Jolnt Chiefa did not belleve this to

\footnotetext{
${ }^{\text {ID1d }}$, p. 442 (see append1x).

${ }^{2}$ Ib1d. p. 417; from a quotation read by senator W11ey. ${ }^{3}$ supre. pp. $50-53$.
} 


\section{4}

true in the realm of public announcements and in the announced policy of containing the war in Norea. ${ }^{1}$ General Collins alluded to Machrthur's disregard of a directive when he sent fmerican troops to the front near the Yalu without so advisine the Joint Chiefs. During the hearings, Macarthur asserted the necessity of doing this because of the military impracticability of drawing a line on the territory short of the Yalu. ${ }^{2}$ The difference of opinion between headquarters in Japan and the administration burst abruptly into print on February 14 when the New York rimes quoted the Far last Commander as statine:

The concept advanced by some that we should satablish a Iine across Korea and enter into positional warfare is wholly unrealistic and illusory. It fails completely to take into account the length of such a line at the narrowest lateral, the rubed terrain which is involved and the relatively small force which could be committed for the purpose.3

This was a definite criticism of a plan which the administration might advance as an oficial solution of the korean problem.

According to administration officials, MacArthur's next controversial statement actually amounted to a nullification of the effect of measures which the United Nations might have taken to ensure an armistice. On March 20 the Joint Chiefs advised the Far East Commander of United

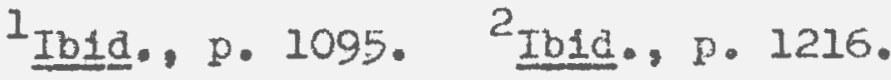

$$
\begin{aligned}
& { }^{3} \text { Ib1d., p. 475; quoted by senator Johnson. }
\end{aligned}
$$


Nations preparedness to discuss "conditions of settlement" with the enemy. It was believed in washington that a further attempt at negotiations should be made before the parallel was crossed again. The military chiefs did not, however, want to restrict operations and requested information on what authority Mackrthur needed in the next few weeks to provide security for his forces and maintain contact with the enemy. I They had already instructed KacArthur to report any request by the Communists for an armistice in the field. This was to be sure that political questions wight be considered in any agreement. 2

On March 21 MacArthur responded that the existing inhibitions should not be increased. Indeed, he continued, because of the military disadvantages arising from these restrictions upon air and naval operations, in addition to the disparity in the size of the opposing forces, it would be practically impossible to clear North Korea of the enemy.

President Truman and his advisers were shocked when General Machrthur issued a public statement that:

the enemy, therefore, must by now be painfully aware that a decision of the United Nations to depart from its tolerant effort to contain the war to the area of Korea through an expansion of our military operations to its coastal areas and interior bases would doon Red China to the risk of imminent military collapse. These basic facts being established, there should be no insuperable afficulty in arriving at decisions on the Korean problems if the

\footnotetext{
$1_{\text {Ibid. . p. } 411 .}$

2Ibid., p. 1197; testimony of General Collins.
} 
issues are resolved on their own merits, without beine burdened by extraneous matters not directly related to Korea, such as Formosa or unina's seat in the United Nations. 1

The Korean nation and people, whlch have been so cruelly ravaged, must not be sacrificed. This is a paramount concern. Apart from the railitary area of the problem where issues are resolved in the course of combat, the fundamental questions continue to be political in nature and must find their answer in the diplomatic sphere. Within the area of my authority as the military commander, however, it would be needless to say that I stand ready at any time to confer in the field with the commander-in-chief of the enemy forces in the earnest effort to find any military means whereby realization of the political objectives of the United Nations in Korea, to which no nation may justly take exception, might be acçomplished without furthex bloodshed.2

Secretary of Defense Marshall was the most emphatic of the witnesses in enunciating the damage done by MacArthur in making this statement. He asserted that proposals the President had planned to make and wich had a chance of terminating the fighting were aropped when "we had spoken again with two voices. . ." 3

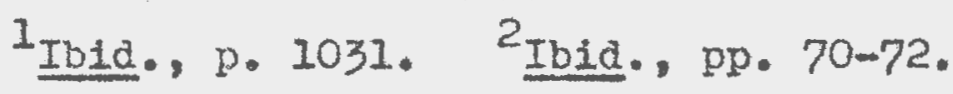

$3_{\text {Ibid. }}$ pp. 344 and 429 . See also Acheson's test1mony (ibid., pp. 1774-75). According to James Reston, this statement by MacArthur did not upset the adrinistrative applecart. Because the Chinese offensive was well organized by this time and the draft of the Eresident's statement actually offered less than Pelping had rejected in January, when the United States had specifically mentioned discussion of Formosa and of Chinese admission to the United Nations, the Chinese Communists would not have accepted Truman's terms (New York Times, May 9, 1951). 
Letter to Joseph Martin

After this statement of March 24 Truman besan to make plans for the removal of Douglas Nackrthur. An excuse for doing so was offered on April 5. House minority

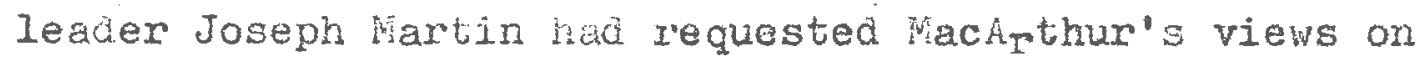
the importance of Asia versus wurope in the world strugile and on the use of Formosan troos to open a second front to relieve the pressure on Korea. He enclosed the text of a speech he had rade advocating Formosan action against the mainlard. In his answer to the Congressman, General Macirthur wrote:

Wy viers and recommendation with respect to the situation created by Red China's entry into the war against us in Korea have been submitted to Washington in most complete detail. Generally these views are well known and generally understood, as they follow the conventional paturn of meeting force with maximum counterforce as we have never failed to do in the past. Your view with respect to the utilization of the Chinese forces on Formosa is in conflict with neither logic nor this tradition. 1

un the respective iraportance of Europe and Asia, General Machrthur wrote, "Here we fight jurope's war with arms while the diplomats there still fieht it with words. - As jou pointed out, we must win. There is no substitute for victory." 2 This letter indicated again that Macisthur did not agree with adrinistrative policy; it criticlaed what Mackrthur always considered the Burope

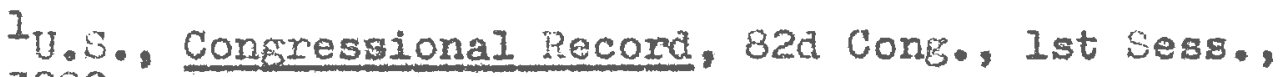
$1951,3280$.

2 Military gituation in the Far East, p. 412.
} 
first pollcy of the Democrats and approved of a policy in regard to the Chinese Mationalists which the administration feared might lead to a world war. Also, these paragraphs definitely involved foreign policy and should have been cleared under the December 6 directive. The Far Fast commander did not request Martin to keep his letter confidential, even after he had received reainder from Waghington to clear policy statements. Thus, on Aprll 5 Representative Martin read the letter before the Fouse. 1

On Warch 31 Henry Hazlitt, editor of the Preeman sent MacArthur the following telegram:

Why do we fail or refuse arms to 400,000 South Korean araftees as reported New York pimes, March 31, dispatch from Taegu? Previous statements President Rheo reported request for such arms.

Macdrthur's answer was:

I have delayed reply to your message of the 3lst pending receipt here of the referenced Hew York Times alspatch. There is nothing I can add to the information therein contained. The issue is one determined by the Republic of Korea and the United states Govemment, and involves basic political decisions beyond my authority. ${ }^{2}$

When in January the JCS had proposed providine arms for these same South Korean troops, it had been MacArthur who had recomended giving the arms instead to the Japanese national police. To make effective use of adaitional equipment, the Koreans noeded nore training. Between this sugsestion of January 6 and the writing of his lotter to

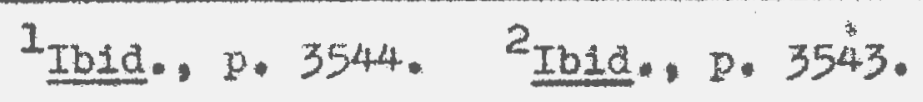


Martin, MacArthur had not made ary different recommendation to Veshington on this question. General Matthew $B$. Ridgway and Admiral Janes A. Van Fleet still recommended that no additional units be equipped. Besides, according to General Bradley, the 400,000 Koreans mentioned in the telegram were not trained reserves. Many were physically unfit; others were suffering from malnutrition. Also, it had been the policy of both MacArthur and Ridgway to use any adaitional manpower avaliable to keep the units they had up to strength rather than to form new units. ${ }^{1}$ 


\section{CHAPTER V}

\section{POIICY AND TRCTICS IN KUREA}

Differine Aims of Machrtiur and Truman

While questioning Secretary of Defense harshall, Senator saltonstall formulatad in plain terms the divergent aims of MacArthur and the Fresident in Korea. ihe jenator spoke of Mackrthur's advocacy of "policles of action on our part that mignt lead us to be able to tell them, "Wow we are going to continue to go on unless you say you have had enough." He plctured administration policy as aiming "to try to kill off enough Red Chinese, when they come on us, so that they say they have had enough. . ." When he asked Hershall if that was not about the difference, the Secretary's roply was "I think that is about it." Marshall adcied that if we inflicted Iosses on the Chanese, we could take the initiative in asking for a cease-fire. Above all, we were seeking a solution which would stop the sacrifice of our soldiers ard prevert a spread of the strugrle. ${ }^{1}$ Machrthur accused the adminlstration of needlessly sacrificing imerican lives by not taking the sterner meagimes against the Chinese which he advocated. Americars 
were horrified at the idea of thousands of their countrymen being killed when the result would not be a total victory, but the prevention of Communist gains. ${ }^{2}$ MacArthur held that if the United States continued the war indefinitely, the fighting would spread and increase the probability of world war III. 2 He urged putting all forces possible into a definite campaign to win. According to General Macarthur, the Chinese ability to wage war had been sreatiy exagerated. A blockade would dismupt their economy and thus make a victory for the west possible. 3

This was certainly not the administration's viewpoint. bashington felt that carrying out Macirthur's proposals might well lead to Russian intervention and a tragic extension of the war. In the words of General Bradley, a war with Red China would be a tragic one "at the wrong place, at the wrong time, and with the wrong enemy." 4 Marshall considered MacArthur willing to risk war with Communist China or the Soviet Union the expense of losing allies and wrecking the "coalition of free peoples throughout the world." 5

According to General Marshall, the situation in Korea was not a stalemate as long as the United Nations had certain powers of maneuver and was inflicting severe punishment. 6 Dean Acheson went further than this, asserting that

$$
\begin{aligned}
& \text { I MacArthur referred to casualty lists often. } \\
& { }^{2} \text { Ibid., p. 145. }{ }^{3} \text { Ibid., p. } 58 .{ }^{4} \text { Ibld., p. } 732 . \\
& { }^{5} \text { Ibid., p. 1007. }{ }^{6} \text { Ibid., p. 1716. }
\end{aligned}
$$


the operation in Korea was a success, for the enemy had been prevented from accomplishing its declared objective of driving the United lations out of Koreg and imposing Comounist rule on the peinsula. ${ }^{I}$ The attainment of a unified, free, and democretic korea could no longer be the military aim of Korea, but should be accomplished by peaceful means. 2

During General Collins visit to Korea after the Chinese invasion, General Vacarthur propased the lifting of four restrictions; in his speech before Congress in April he ajain made four proposals for the amelioration of the United Nations' position. These were:

First, the intensification of our economic blockade against China. Second, the imposition of a naval blockade asainst the China coast. Third, removal of restriction on air reconnaissance of China's coastal areas and of Manchuria. Fourth, removal of restrictions on the forces of the Republic of China on Formosa with logistical support to contribute to their effective operation against the Chinese mainland. 3

The nost drastic of the recommendations was modified from the bombing of Manchuria--although the general still undoubtedly preferred such action--to a reconnaissance of China's coastal area and Manchuria. The seneral advocated carryine out these proposals, even if the United rations did not agree to them. 4

$$
\begin{aligned}
& { }^{1} \text { Ibid., p. 1716. } \\
& { }^{2} \text { Ibid., p. 1729; cf. Bradley's testimong (ibid.,p955). } \\
& { }^{3} \text { Ibid., p. 3556. }{ }^{4} \text { Ibid., p. } 198 .
\end{aligned}
$$


Hconomic and Naval Blockades

Machrthur's first sugsestion before Congress was to impose an economic blockade on China, thus depriving her of needed materials from the Western nations. Administration witnesses agreed on the advisibility of this measure. In fact, other countries had already taken measures to make sure that Feiping did not receive strategic materials. ${ }^{1}$ There had been a general embargo by Western countries on the export of munftions to the Communist Chinese ever since they had been in power. Embargoes had beon placed on other products by the United States until, by December of 1950, no exports from inerica to lelping were allowed. By the end of 1949 Luropear allies had embargoed shipments to the Soviet bloc of about two-thirds of the industrial items which our experts recarded as of prime importance. The list of forbidden articles was expanded in 1950 and 1951,2 although, as General Marshell testified, the blockade had been effective only to a limited extent. 3 The Britigh had not been willing to go as far in ensuring this blockade as had Americans. As Senator Wiley pointed out, the Colonial Office had reparted a sale of 120,000 tons of natural rubber by British Malaya to China in the nine months preceding May 1951. 4 This controversy over an econonic blockade was eased somewhat during the hearings wen on May 18, 1951, a

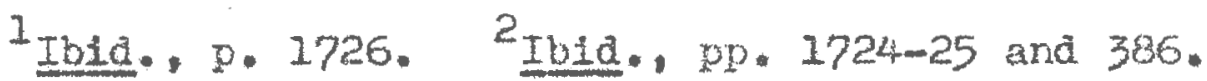

$$
\begin{aligned}
& \text { 3.bia., p. 328. }{ }^{4} \text { Ibja., D. } 424 .
\end{aligned}
$$


United Nations resolution called for an embargo on stratefic exports to Communist China. ${ }^{1}$

Although MacArthur and the administration agreed on the importance of an economic blockade, there was a difference of opinion on whether a naval blockade of the Chinese mainland should be mounted. Macarthur pictured an actual blockade as threatening the destruction of millions of Chinese through starvation. ${ }^{2}$ Eike MacArthur, Generals wedemeyer and Chennault favored a naval blockade, even over United Nations' objections. 3 General Marshall believed that a blockade might eventually have a serious effect on the Chinese Communist government. 4 Nevertheless, he saw the danger of an early Russian entrance into the war if the Navy ventured as far as port Arthur. 5

General Collins believed that a naval blockade would have to include Dairen and possibly Vladivostok. 6 Bradley opposed a naval blockade as an act of war which would affect

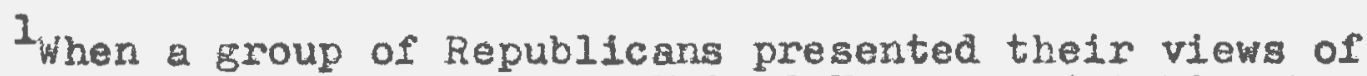
the hearings, they accused the United Nations of taking hesitant steps toward ensuring an embargo. As an appendix to the report they included sumaries of the steps different countries had taken to carry out the May 18 resolution (ib1d., pp. 3587 and 3625-55).

Ibid., p. 179. Admiral Sherman agreed with MacArthur'sestimation that the Navy had enough ships to carry through a blockade (ibid., p. 1527).

${ }^{3}$ Ibid., pp. 2314 and 3342. ${ }^{4}$ Ibid., pp. 355 and 359.

${ }^{5}$ Ibld., p. 482. According to Rovere and Schlesinger, Japan under Machrthur had sent over 19.5 million dollars worth of materials to China, $85 \%$ of which was iron and steel sheet, machine tools, etc. (Rovere and Schlesinger, p. 222). 
not orly Chine but also Russian Port Arthur and British Hons Kong. 1 . According to secretary of State Acheson, the success of a naval blockace would depend on certain circumstances; a discussion of these circumstances was deleted from the record of the hearings. ${ }^{2}$ while the blockade of Worth Korea did not involve any extension of hostilities or the possible prejudicins of the security of other countries, the imposition of a naval blockade of China might raise these questions. 3 In fact, if the Urited Nations could get an effective economic blockade, there would be less necessity for a naval hindrance of ships entering Chinese ports. 4

\section{Bombing Manchuria}

Amore the four proposals made to General Collins, General Machrtiur included the bombing of Manchuria. When he appeared before Congress in April, he modified this sugestion to an advocacy of air reconnaissance over lianchuria, a nild noasure in comparaison to bombing. During the hearings he returned to the ldea of bombing Chinese territory and asserted that bombing the Chinese fistern Railway would not cause a general war. 5 To take care of the Chinese hordes which were tren swooping down into Korea, PacArtbur had been given permission to bomb the Korean end of the bridges over the Yalu. 6 The JCS had also proposed

$$
\begin{aligned}
& \text { I Military sitution in the Far East. pp. } 742 \text { and } 924 . \\
& \text { Ibid., p. 1865. 3 Ibid., p. 1831. }{ }^{4} \text { Ibid., p. } 1727 . \\
& 5 \text { Ibid., p. 252. } 6_{\text {Ibid. }} .741 .
\end{aligned}
$$


permitting American planes to encage in "hot pursuit" over Chinese territory whenever enemy planes were caught in korea. Acheson and Truman concurred in the advisability of doing this, since, as General Vandenburg had suggested, it would greatly improve the morale of the pilots. I The secretary of State requested the other nations engaged in Korea to submit their reaction to the question of hot pursuit, although reserving the right of the United States to go against the general opinion. ${ }^{2}$ when Acheson reported to the Defense Department the consensus of the allies that Unfted Nations planes should stay away from Manchuria, any immediate plans for continuing flights over Manchuria were dropped. 3

By the time this disapproval was received, the United Nations forces were about two hundred miles south of the Yalu River, thus leaving plenty of room for chasing Communist planes without going into Manchuria. 4 Accordine to General Vandenburg, although hot pursuit would have been good for morale, with the linited air power available it would not have been decisive in winning the campaign. 5

${ }^{1}$ Ibia., pp. 1132 and 1388. ${ }^{2}$ Ibid., p. 328. ${ }^{3}$ Iuid., pp. 2278-79.

${ }^{4}$ Ibid., p. 507. MacArthur had told Truman at Wake Island that if the Chirese Communists attacked United Nations forces, the air force would "slaughter" them (supra, p. 45). When the chinese did counterattack, the air force did not halt them (New York nimes, May 13, 1951).

'Ibid., p. 1388. O'Donnell's testimony showed that U. s. airmen in Korea had long felt a sense of frustration at the limitations imposed by the policy of limiting the war; in his opinion, rever had so many "Inordinate" advantages gone to an enemy in a great conflict (ibid., p. 3105). 
Washington even forbade the Air Force to bomb the North Korean port of Racin. However, one raid had already been carried out when this order was given and a second had been diverted because of weather. The State Department objected to any further action against the port because of its location only seventeen miles from the Russian border. ${ }^{1}$ The Joint Chiefs agreed to the validity of this objection; in addition, they saw the port's usefulness to the North Koreans as being somewhat limited, since a railroad from Racin down the coast of Korea had not been completed and since Racin was not as good a supply point for the North Koreans as was Chongjin. Supplies could be stopped by cutting rail and road lines at a point farther from Russia. 2 As for the question of bonbing Manchurla itself, General Collins could aiscover no specific request from hacArthur to do so, although the Far East commander had raised the possibility of such action as early as November 7 when stating inat restrictions on United Nations forces had provided a sanctuary for the enemy. 3 shortly after this he indicated his belief in the feasibility of carrying out operations in Korea to prevent reinforcements from crossing the Yalu. It was when Colling visited him in December that MacArthur requested that he be allowed to bomb Manchuria. 4

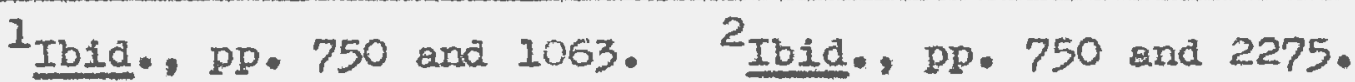

3Ibid., p. 1288. According to Bradley, this was after MacArthur had been given permission to bomb the Korean end of the bridges over the Yalu (1bid., p. 741).

$$
{ }^{4} \text { Ibid., p. } 1290 .
$$


Administration officials would not admit that the United Nations could have attained any great advantage by bombing beyond the Yalu. According to Marshall, ground forces may have suffered in a rather remote way from Air Force inability to bomb lines of supply and arsenals at Mukden and Harbin. ${ }^{1}$ Although American air power could have destroyed many Chinese planes; these planes had really not been very effective in action and had not attacked Allied ground troops. ${ }^{2}$ General Collins maintained that for such action to be effective, the Air Force would have to bomb not only airfields but also warehouses and other buflaings which were often in towns. 3

Bradley pointed out the nec ssity of using the available air and naval forces within Korea. Sufficient planes and sea craft could be gathered for MacArthur's projects only by stripping other operations. 4 Air Force Chief of Staff Hoyt Vandenberg spoke of the "shoe-string" Air Force when it was viewed in its world-wide comitments. 5 Even MacArthur admitted that the air power was not strong enough to defend both the United States and American troops in Europe. 6 According to Vandenburg, all-out use of the air forces would not defeat Communist china, although it might make the Chinese negotiate.? At the time of the hearings,

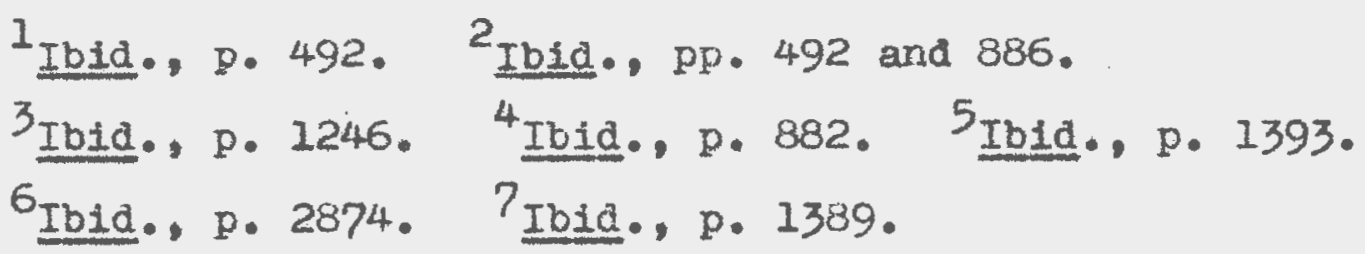


the Air Force had a Korean supply line of about two hundred miles to work on, and bombing Narchuria would be inadvisable strictly fron a military viewpoint because of the danger of extendire the war. Furthermore, in the advent that Russia should enter the war, it would be very difficult to supply troops in Korea or to get them out. 1

According to Karshall, the effectiveness of bombing supply depots in China would be less than sometimes asserted because the Chinese had certainly dispersed supply depots against the possibility of air attack. ${ }^{2}$ As strategic bombing consists normally of attempting to destroy sources of production, it could not be applied to China, for equipment in Chinese possession came mostly from Russla. Furthermore, the chinese would be able to repair rapidly any damage done. 3

Several witnesses before the committees were not so adamantly against bombing Manchurla as were Generals Marshall and Bradley. General Wedemeyer agreed with MacArthur that bombing Manchuria was a calculated risk the allies should have taken. He also belleved that the decision on whether to do so or not was rightrully MacArthur's, since a "comander in the field should be given no restrictions whatsoever in carrying out his mission... ."4 General

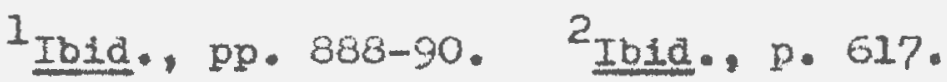

3. Ibia., pp. 744 and 965; testimony of General Bradiey.

${ }^{4}$ Ibid., pp. 2315 and 2516. Generals Badger and Barr agreed With General fedemeyer (ibid., pp. 2798 and 2958). 
O'Donnell believed that we should have bombed Manchuria in November 1950, but could not answer whether bombing was still feasible in view of the primary duty of maintaining a strong strategic Air Comand in a position to guard against Russia. ${ }^{1}$

\section{Formosa}

The Joint Chiefs of Staff viewed Macarthur's proposal for removal of restrictions on the forces of the Republic of China with misgivings. Expressing the belief that "the interests of the United States of America coincide with anyone who is opposed to Communism," MacArthur advocated complete support of the regine. He maintained that although parts of the rormosan government could be critisized, it had no more defects than some other democracies did. ${ }^{2}$

One must look back to 1949 to see the origins of the argument over the importance of Formosa and the role it could play in the struggle agatnst Red China. Two studies in September and october of that year had indicated that economic and diplomatic methods might not be successful in keeping the island in friendly hands. In view of these reports General Wedeneyer sugested minimizing the damage from the fall of pormosa by explaining the situation over the Voice of America. 3 On January 3, 1950, the United

\section{${ }^{1}$ Ibid., p. 3072. ${ }^{2}$ Ib1d., pp. 111-12.}

I Ibid., p. 1672. General Wedemeyer asserted that the final policy memorandum had never been referred to him and he doubted that it had ever been submitted to the Department of Defense (ibid., pp. 2296-97). Acheson held that 
Press published an article beginning:

The United States state Department has notified its attaches that the loss of Formosa, island redoubt of the Chinese Nationalists, to the Communists was to be anticipated. The Department said the public must be sold on the idea that the island is of no strategic value in order to prevent the loss of prestige at home and abroad.

Referring to this article, Senator Knowland accused certain representatives on rormosa of following a course meant to undermine the Nationalists and of repeatediy sending false reports that the island would fall. He requested the names of those who had drawn up the Formosan Document. Acheson refused to five them, however, on the grounds that all responsibility rested with him as secretary of state and because releasing the names would incresse the reluctance of officers in the State Department to work in certain controvergial areas where they might be accused of unorthodox ideas. ${ }^{1}$ As a justification for putting forth the formosan Document, Acheson spoke of a necessity of minimizing the importance of a territory which might be lost. ${ }^{2}$ He attempted to explain the meaning behind several controversial statements in the document. Referring to the phrase "largely because of a mistaken importance to the United States defense in the Pacific," Acheson denied that this meant that the island was of no strategic importance. It

the Interdepartment Coordinating Staff, includins representatives of the Army, CIA, and ECA, had seen the document without aking any suggestions to alter it (ibid., p. 1828).

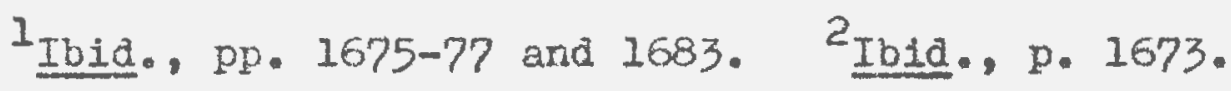


was intended to counteract the effect of talk that the loss of Formosa would be catastrophic to the sccurity of the United states and would throw the defense line back to the California coast. In reality, all means short of employing American troops would have been used to prevent the fall of Formosa. ' Acheson summarized Anerican policy toward Taiwan from 1948 until the invasion of South Korea: (I) Formosa had strategic inportance for Anerica, (2) the 1sland should be kept out of the hands of a hostile power, and (3) under existing conditions it was not possible to promise to commit united states forces to Formosa. ${ }^{2}$

Orficial policy changed in June 1950. On the twentyfifth of that sonth president iruman anrounced our determination to prevent an invasion of formosa from the mainland. 3 He ordered the seventh Fleet to Formosan waters to "neutralize" the islund and called on Chinese Nationalist forces to cease afr and sea operations against the mainland. On the other hand, the State Department informed MacArthur that if Chiang Kai-shek offered troops, he should refuse them. The army of Taiwan was needed on the island

${ }^{1}$ Ibid., pp. 1804-05. A debate over whether the Formosan Document should be published ended with Acheson IosIng his fight against publication. Maintaining that he bad furnished the document to the committees with the understanding that it would not $g \circ$ into the public record, Acheson pointed to the possibility of Russia using the official document as a way of discrediting the Voice of America. Since a summary had already been released, it appears that Acheson was thinking of the damage an official release would do to the administration.

$$
\text { 2Ibid., pp. 1671-72. 3 Ibid., p. } 1000 .
$$


to defend it against the Chinese Reds in the event that they should attack. 1

After General MacArthur visited the island of Formosa in July, ${ }^{2}$ he made several recommendations on arms and equipment needed by the Formosans. He did not recommend using the troops in Korea. After the Chinese invasion of Korea, nevertheless, he began to blame failures in the peninsula on the fact that Chinese Nationalist troops were not being used. Accordine to MacAxthur, Chiang Kai-shek's forces had improved, and, wth so many Chinese Communists in Korea, it was unlikely that Peiping would mount an offensive against Taiwan. 3

There were several reasons advanced by the Joint Chiefs for their opposition to using Formosan troops in Korea. According to Marshall, there was a continued need for armed protection of the Formosan island. As late as March 195 a aission sent to Formosa had pictured the troops as ill-prepared for battle. Since some of our allies no longer recognized the Nationalist government, they might well not welcome the iciea of tuis eovernment's troops flehting in Korea or engaging in diversionary activities from Indo-China. If the Chinese went to the mainland in junks, as MacArthur suggested, ${ }^{4}$ the United States might

$1_{\text {Goodrich, }}$ p. 110-11, questions the wisdom of sending the Seventh Fleet to patrol the waters between the island and the mainland when many of the countries in the UN did not recognize the Nationalist regime.

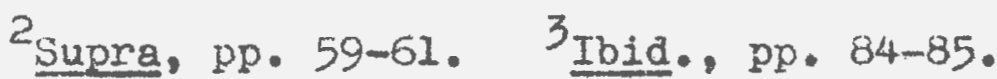

${ }^{4}$ Ibid., p. 24. 
well become involved in fighting in China, for the Nationalist army would require more logistical support and better trained troops to carry out a successful campaign on the mainland. ${ }^{1}$ one had to consider, too, the possibllity that the ussians would picture any return of the Nationalists to the mainland as a causus belli and would more actively support the Red Chinese.

The Military and the Civilian

If the Joint Chiefs of staff had to take more factors into corsideration when making a decision than did MacArthur, so did the Fresident and the state Department have to weigh other interests when making and carrying out policies. The proper roles of the Departments of Defense and State in making decisions were important subjects discussed during the hearinfs. The role of congress in declaring war and in sending troops abroad raised partisan debate, as did the state of preperedness of the country and the question of universal military training.

Although General MacArthur agreed that "at no time in our system of government is there any question of the civil administration being in complete control," he also asserted that "there should be no non-professional interference in the handing of troops in a campaign." 2 If this hands-off 619.

I Ibid., p. 164; testimony of Iradley; cf. pp. 337 and

${ }^{2}$ Ibid., p. 289; af. Hedemeyer's statement on a commanding officer's role in carrylng out his mission (supra, p. 79). 
attitude on the part of civilians were carried out in a war, the role of the President as chlef of state would be infringed upon. The idea that military plans can be carried out without being adapted to the diplomatic situation ignores the political connotations of some military actions, such as the bombing of cities.

Before the Joint Chiefs of staff issued definite orders on any problem which might lead to political repercussions, they asked the opinion of the state Department on the question at hand. I Louis Johnson had found his predecessor as Secretary of Defense, James Forrestal, concerned about the domination of the State Department over Defense. However, after a system of liaison between the two departments had been set up, Acheson was, in Johnson's opinion, very cooperative in carrying out joint planning. 2 As a result of consultations, the political factor might be the determinant, for instance in the decision not to bomb near the Manchurlan border, ${ }^{3}$ but this was cecided before an order was given, not by changing directives. 4 In questions where there was a difference oI opinion between state and

${ }^{1}$ Ibid., p. 898; testimony of General jradiey. A directive to MacArthur from the JCS was supposed to contain only military material. When political reasonings entered the picture, it was the President who communicated with MacArthur; thus, Truman included political decisions in his note to the general on January 13, 1951, which had been excluded from the January 12 message (ibid., p. 905).

Ibid., pp. 2577 and 2594. 3Ibid., p. 502.

${ }^{4}$ Ibid., pp. 740 and 1760 ; testimony of Bradley and Acheson. 
Defense, Marshall could not recall any instance where the Commander in Chief had acted adversely to the Department of Defense in relation to the state Department. ${ }^{1}$

"Var's very object is victory, not prolonsed indecision. In war, indeed, there can be no substitute for victory." In these words, Gencral MacArthur expressed the military strategist's view that one side or the other must win a war. The concept of limited war in which the armed forces attempt only to prevent the enemy from making advances was alien to the American idea of success, notwithstanding the fact that the lar of 1812 was one in which neither side won. Although Republicans often stated that a cessation of hostilities with the communists in control of territory rorth of the thirty-eigth parallel would be a victory for the enemy, ${ }^{2}$ and some people still state that we lost the war in Korea, it seems to many others, including this writer, that by preventing the Communists from making territorial gains, the West achieved a victory.

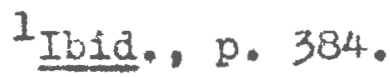

${ }^{2}$ See conclusion of Republican Senators to this efiect (ibid., p. 3605). 


\section{OTHER NATIONS AND ROREA}

Russia and the Korean War

In deciding what neasures should be taken againgt Communist China, the allies had to consider what Russia would do, especlally in view of a 1950 sino-Russian treaty. In this pact Russia and China promised to prevent the "repetition of aggression and violation of peace on the part of Japan or any other state which should unite with Japan, directly or indirectly, in acts of aggression." I Russia might construe this treaty to denounce even the flying of airplanes from Japan to carry on the struggle agalnst China as an aggressive act, if she so wantod. ${ }^{2}$

Douglas MacArthur refused to speculate on whether bombing Manchuria would requir Russia to carry out the assistance called for by the alliance. He countered by declaring that losses in Korea could not go on forever. There was no certainty that Russia would stay out or come in; on these things the country had to take a certaln risk. ${ }^{3}$ Indeed, the Soviet Union seemed to be less and less

I Ibid., p. $993 .{ }^{2}$ Ibld., p. 406; testimony of Marshal1.

3 Ibid., p. 66 ; cf. p. 40 where MacArthur states his recommendations might not confine the conflict to Korea, but 
linked with the Korean Har. $^{1}$ Moreover, even while receiving air assistance and supplies, the chinese might not want Soviet forces in their country. ${ }^{2}$ For one thing, China wanted Manchuria to remain part of her territory, a status which might be endangered if Russians were admitted on a large scale to China proper. As for American designs on Manchuria, Macarthur did not believe that a bombing of that territory would alter the fact that Russia knew that we had no 1mperialist designs there. 3

The administration did not agree with MacArthur's rather sangulne view of the possibility of Russian entrance into the war. President Truman had decided that the risk of war from bombing Manchuria was too great. The soviet Union and Communist China had called attention to the treaty between them in connection with Korea and the alleged rearmanent of Japan. Also, if Russia failed to live up to the terms of the treaty, her influence in the far East would possibly be threatened. This was true even if the terms of the treaty were vague enough for the Russians to interpret it as they wished. 4

That Russia would not necessarily respond to action on the part of the United States was, according to Acheson, one of two assumptions made by MacArthur in drawing up his

that they would give us an opportunity to hit the enemy before he hit us.

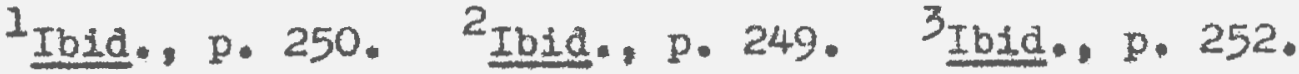

4 Ibid., p. 480; testimony of Marshall; cf. p. 741, testimcny of Bradiey. 
progratr. The administration, however, was aware of three actions which the Kremlin might initiate: (1) turning over to the Chinese large numbers of planes with crews for retaliatory action, (2) intervening in Korea with a half million or more zround "volunteers," and (3) precipltation of an all-out war. ${ }^{1}$ MacArthur's second essumption was that time was not necessarily on our side in the buildine up of armed strength. In contrast to this idea, the administration did belleve that tirse was on our side, not that we would match the Soviet Union "man for man and tank for tank," but that we could build on effective deterrent force. 2 The hearings brought forth solwe comments on Russian aid in the Korean War. Many of the statements on this subject were deleted on security grounds from the published testimony. Nevertheless, General MacArthur did state that the attack on Bouth Korea could not hive been launched by the North Koreans without supplies furnished by the Soviets? Bradley answered questions of Senator Harry Byrd with statements that MIG 15's, fast Russian-built jets, were used to combat United Nations approaches to the Yalu and that tanks and wost of the artiliery were of Russian manufacture. 4

Both General MacArthur and General Bradey spoke of the difficulty of discovering exactly how much influence

I Ib1d. pp. 1718-19. General Bradley testified to Russian wilingness to go to war on pp. 751 and 942.

$$
\begin{aligned}
& { }^{2} \text { Ibid., p. 1720. 3 }{ }^{3} \text { bid., p. } 173 . \\
& { }^{4} \text { Ibid., p. } 995 ; \text { cr. testimony of Marshall, p. } 623 .
\end{aligned}
$$


Russia had on China in 1950 and 1951. 1 Marshall was more positive on this point when he stated, "I have gone on the assumption that she [China] was operating not only in conjunction with but literally under the direction of the Soviet Union."2 Although Russia and Chlna were acting together in Korea, Acheson mentioned the continued State Department consideration of a posgible split between the two powerful countries. 3 Indeed, as Bradley pointed out, no country had been able to dominate china very long. 4

In considering measures which might be taken in Korea, the adrintstration had to keep in mind the relative strength of the United States and of Russia. Here asain there was disagreement with MacArthur. The general firmly believed that the Soviet government had not stockpiled sufficient material in Siberia to maintain a major ageressive campaign in Asia for any length of time.5 General sherman showed himself to be in sympathy with this view of Russian strength when he stated that the real deterrent to Russian aggression was the fear of being soundly beaten. ${ }^{6}$ In refuting this estimate of Russian strength, Marshall assumed a Russlan possession of the A-bomb, an increasing relative military power, and a growing efflclency of weapons.?

I Ibid., pp. 144 and 1001.

Ibid.. p. 659. Acheson also expressea a belief in a closer connection between Communist China and the Kremlin than Machrthur saw (ibid., p. 1923).

$$
\begin{aligned}
& { }^{3} \text { Ibid., p. 1776. }{ }^{4} \text { Ibid., p. 1001. }{ }^{5} \text { Ibid., p. } 130 .
\end{aligned}
$$

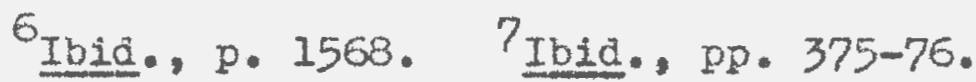


whe United Nations in Korea

In deciding what measures could be taken in Korea, the United Nations technically had the major role. In reality, the United States had the real power of decision, tempered by its desire to keep the support of its allies. Since there was no Military Staff Committee in the United Nations, President iruman became the agent for all the countries. 1 Although the United States was to carry out Unitec lations resolutions on Korea, it did not always act in pursuance of a UN resolution. On several occasions, e.g. on July 7 and October 7, the American government acted previous to or at the same time it was seeking approval for an action. 2

General Marshall explained the official line of command for orders going to Korea. From general United Nations resolutions the JCS prepared a "precise directive," taking into consideration all the military involvements and implications. Directives were forwarded to the secretary of Defense and the president, and if very important, to the National Security Council. Any political questions involved were discussed with members of the state Department. Hachrthur's reports originally went through the JCS on their way to the United hations. Later, when reporting exclusively on military operations, the United Nations Supreme Comander reported directly to the intarnational

$$
{ }^{1} \text { Ib1d., pp. 1938-39. }{ }^{2} \text { Ibld., pp. 326-27. }
$$


body. I Generally this worked well. Nevertheless, according to Acheson, General MacArthur overstepped his authority in his twelfth report to the United Nations by stating his own views in what was supposed to be a "factual recitation of military events." When MacArthur denied the validity of State Department objections, the report was forwarded to the Untted Nations. 2

Dean Acheson believed strongly in the necessity of maintaining international support for actions in Korea, since they were being taken in the name of the United $\mathrm{Na}-$ tions. 3 Because the main resolutions of the world body were in support of vieorous war against aseression in Korea, they were little discussed in the hearings. However, several Senators did attack an Indian resolution of January 11. 1951, calline for a five-membor group to consider cease-fire proposals and an armistice. The Soviet Union, the United States, Great Britain, Communist China, and one other country were to be on the committee. The Senators claimed that the proposal made the concessions of discussing Formosa and of recognizing Red China by including her on the committee. Senator Knowland referred to an article in the New York pimes in which it was stated that Ambassador Austin had voted for the resolution in expectation of a Chinese Conmunist refusal to see the committee. According to Knowland, this had been a dangerous wager because of the

$I_{\text {Ibid., p. } 989 .}$ Ibid., p. 1981.
$3_{\text {Ibid., pp. 1940-4I. }}$


possibility of an acceptance. ${ }^{1}$ In Acheson's opinion the cease-fire proposal did not promise Formosa and China to the Communists. It was meant to say merely "if you people stop your defiance of the United Nations, then you will have the chance to discuss, as you had a chance before this defiance, these questions in which you are interested." He further averred that although we did not consider these questions part of the Korean situation, wo could not prevent othor people discussing them. 2 Acheson could find nothing in the proposal which indicated how dany nations would confer on the cease-fire, and we should have insisted on the inclusion of Nationalist China in any discussion group. 3

Another subject involving the United Nations was the seating of Red China in the United Nations. Part of the discussion centered on whether Communist China's entrance was a procedural question not subject to the veto. Mcheson spoke of our hope of keeping the lied regime out of the United lations by a majority vote. If evidence showed that a minority supported our position, we would request an

\section{${ }_{\text {Ibid. }}$ p. 523.}

Ibid., p. 1784. According to Marshall, the JCS had recomended the omission of these questions from the ceasefire discussions. However, they made no recommendation as to a discussion of these questions in a final settlement, a sugestion made in the fifth principal of the Indian resolution.

Ibid., p. 1969. The proposals are outlined on page 1967 of the hearings. 
opinion of the borld Court on the Charter provision that the epublic of China should be the permanent member of the Security Council. I If a veto of the admission was being consiaered, an opinion of the 'orld Court on record that the entrance of Italy was a vetoable question could be taken into consideration. 2

\section{The Allies}

Plot all member rations of the United Nations fought in Korea. Of course, Russia and her satellites opposed all United Nations actions to deal with the ageressor. Others made no contribution of manpower or material. But there were sixteen countries which sent units to firht with American and Korean troops. During the hearings Senators repeatedly questioned the contributions of these countries. Were they contributing their share of men and material? Here they too anxious to compromise with the agsressor and with Russia? Had the allies put pressure on the administration to remove racArthur? Was the administration favoring Hurope at the expense of Asia?

Many Senators pictured the allies as not doing as much as they could to support the Korean war. Although military officials appearing before the comitutecs cenerally areed with this judgment, the secretaries of state and Defense pointed to some of the reasons for this. Acheson

I Ibid., p. 2023. Senator Snith opposed Communist China's entrance into the UN because Russia was in control there and this me ant a conquest by an external power. I Ibid., p. 2024. 
spoke of the allies as "painfuliy aware" of the inability to do all they would likse to do. For some time the Eritish had been carrying on guerilla warfare in Falaya, while France had been struggling to maintain her position in Indo-China. 1 Marshall Dentioned the inability of some countries to do nore because of internal political issues. 2

In October 1950 the United States might even have discouraged other nations from sending troops, since we considered the war near an end. Then too, we had turned down some offers of less than thousand troops, for MacArthur had requested that all units accepted have at least this many men. Furthermore, when the United States would have had to furnish all equipment, training, transportation, and logistical support for the troops offered, they were not accepted. 3

Secretary of State Acheson did not think the allies were too anxious to compromise. The foreith ministers of the Unfted States, France, and Great Britain had discussed the importance of limiting the war and were in full accord on major measures in Korea. 4 on the other hand, when ColIins was asked whether the allies were giving us full support through approval of our actions, his answer was that he did not think they were supporting us to the extent they should. 5

$$
\begin{aligned}
& 1_{\text {Ibid., p. 1772. }{ }^{2} \text { Ibid., p. } 607 .} \\
& 3_{\text {Ibid., pp. } 950 \text { and } 980-81 .}{ }^{4} \text { Ibid., p. } 1880 . \\
& 5_{\text {Ibid., p. 1225. }}
\end{aligned}
$$


Machrthur held that, if necessary, the United States should go it alone in Korea; he believed, however, that his plans for victory would be supported by a majority of the united Nations. I If to help an ally were in the American interest, the country should do so; if to help an ally ran contrary to American interest, the country should not do so. 2 This point of view did not accord with Bradley's idea that propasanda, not military might, would help the United States to win the war. To win in this field the American government would have to cooperate with other nations having the same ideals and objectives. 3

As for alleged pressure from other countries to remove MacArthur, Acheson asserted that they had opposed the Supreme Commander's policies several times and were worried about some of his statements. 4 There had, however, been no pressure brought on the administration to replace the general as leader of the United Nations troops. 5 After his removal, the New York Imes reported a general approval of Truman's action by the allies, with a consensus that it should have taken place earlier. 6

\section{Europe versus Asia}

During World War II General MacArthur often complained of the administration's policy of trying to bring

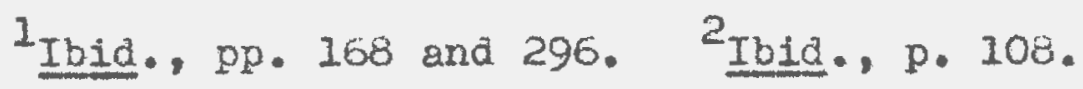
${ }^{3}$ Ibid., p. 730. ${ }^{4}$ Ibid., p. 1733. ${ }^{5}$ Ibid., p. 1879. 6 New York Times, April 12, 1951. 
the war in surope to a finish before eiving all-out suppurt to his forces in the Pacific. ${ }^{1}$ During the Korean Var he voiced the same complaint. He disarreed with the policy of holding a large number of troops in Europe under the supposition that Russia's real aim was to conquer these industrial countries. With this in mind he had written to Coneressman Partin this comment:

It seems strangely dificult for some to realize that here in Asia is where the Communist conspirators have elected to make their play for global conquests, and that we have joined the issue thus raised on the battlefiela; that here we fingt ifurope's war with arms while the diplomats there still fight it with words; that if we lose the war to communism in Asia the fall of Europe is inevitable, win it and jurope most probably would avoid war and yet preserve freedor. 2

Generals Marshall and Bradiey held that Russia's main goal was to achieve domination over Surope and that the United states must ensure the freedom of that vital area. Europe's manpower of three hundred million and her great industrial capacity made her the bulwark against commuism. 3 Air bases on the continent were essential for maintaining a striking power which could reach industrial cities of the Soviet Union. Moreover, if the United States lost Europe, it would lose Middie East oil, bases, and strategic materials. 4 Added to the communist bloc, these resourses would greatly increase Russia's strength as an opponent. 5

I Courtney Whitney, MacArthur: His Rendezvous with History (Now York: Alfred A. Knopl Co., 1956), pp. 36-37. 2 Military Situation in the Far Iast, p. 3544. ${ }^{3}$ Ibia., p. $731 .{ }^{4}$ Ibid., p. 883. ${ }^{5}$ Ibia., p. 742. 
98

General Machthus adnitted during the hearings trat perhaps he did not know all the factors which led the administration to place such a stress on surope. When Senator McMahon expressed a desire to know how MacArthur would defend the American nation, Machrthur replied, "That doesn't happen to be my responstbility, senator. My responsibilities were in the Pacific, and the Joint Chiefs of Staff and the various aencies of the government are working day and nicht for an over-all solution to the global problem:"1 
CHAPTER VII

CONCLUSION

The committee hearings ended on June 27, 1951, almost two months and over two million words after their beginning. On August 17 the two comittees convened once more and adopted a resolution to transmit the hearings, records, and appendices to the senate without filing a report or reaching any conclustons. Nevertheless, members could submit their private views to the chairman. Subsequently, a group of Republicans filed. a long and virulent report. ${ }^{1}$ In a summary of witnesses testimony, these pepublicans pointed to the testimony of Vice Admiral Badger as conclusive evidence that a United States failure to provice arms caused the downfall of the Republic of China, althugh admitting that General Barr contradicted this view. General Hurley's testimony supported the thesis that Yalta was one of the greatest tragedies in our history, while General O'Donnell estimated the Air Force of being capable of carrying out MacArthur's suggestion of

$I_{\text {Republicans signing the repart were Style Bridges, }}$ Alexander Wlley, H. Alexander Stith, Bourke B. Hickenlooper, William F. Knowland, Harry F. Cain, Owen Brewster, and Raiph Flanders. 
bombing warchuria. They thus claimed vindication of their point of view. In their opinion, little could be learned from the testirnony of General 3radey or the Joint chiefs, since it would have been embarrassing for them to contraaict the ecretany of referse or to oppose administration policy.

Whese republicans outlined thirty areos of "arreement" revresenting "common-sense conclusions which enyone resardless of political party would draw aster the facts had "een set forth." The preface to these items read, "The conviction that the administration's Par last policy was one of appeasement toward communism was proven to be fact as a rasult of the investigation." This statement is indicative of the tone of tze rest of the report. The administration might well have aereed with the judgment of the Genators in a few of the areas, e.E., that the Fresident had the right to remove General lacArthur, that MacArthur never violated military directives, that the recommendations offered by the general were based on his desire to bring about a victory. Other of the "agreements" were slanted in such a vay that they conveyed a criticism of the administration's policy, e.e., that the military potential of the United states after lorld ar II was not maintained at a level comensurate with our political commitiments or financial expenditures and that limited war is impossible to define. ${ }^{1}$ 
After condeming the administration in its post-war Far East policy and accusing the State Depertment of harboring Comunists, the Senators supported a freater use of the air and naval forces by following MacArthur's recommendations. They contended that this would ensure the victory which the "lamoral policy of killing more Chinese Communists" was not likely to produce. 1

In their conclusion, the Republican Senators expressed the belief that a peace based on the division of Korea at the thirty-eighth parallel would be a victory for agfression. 2 In a separate statenent Henry Cabot Iodge, Ir. agreed with the commitiee report on most questions, but placed more emphasis on the Korean War. ${ }^{3}$ In a much more reasonable report Senator Saltonstall agreed with most of the conclusions of the other Republican senators, but not with the bases on which they had been predicated. He also emphasized a point completely ignored by his colleaguesthat General MacArthur's statements caused consiàerable doubt in the world as to his support of the United Nations" policies. He correctly judged the importance of the hearings in influencing tre administration on the importance of (1) keeping Formose out of Communist hands, (2) keeping Red China out of the Unfted Nations, and (3) indefinitely delaying Arerican recognition of Comunist China. 4

$$
\begin{aligned}
& 1_{\text {Ibid., p. 3590. }}{ }^{2} \text { Ibid., pp. 3600-05. } \\
& 3_{\text {Ibid., p. 3659. }}{ }^{4} \text { Ibid., pp. 3659-60. }
\end{aligned}
$$


Wayne Morse, still a Republican at this ti, showed his independence by criticizing the Republican report as "very highly partisan and biased," especially in avoiding a discussion of whether MacArthur's conduct justified his removal. In Morse's opinion, it did, especially because of MacArthur' $\mathrm{s}$ ultimatum to the Chinese leaders to neet with him to negotiate a peace. Although deploring the emphasis Republicans put on the ousting of the Nationalists from China proper, he thought the Democrats should have insisted on Ereater control of the aid they gave to the Nationalists. 1

Democrats had no general report on tho hearings. They were content to let the hearings themselves rest as evidence of Truman's justification in recaling MacArtinur. There was general praise of the way in which senator Russell had conducted the hearings.

Results of the hearings were both $z$ ood and bad for the country. Arthur Krock pointed out scme of these results in an article witten shortly before the end of the sessions. Machrthur's testimony led to protests against the shipment of stratefic naterials to Communist China and an embargo on these goods imposed by the United Nations. The reasons for which the administration had dismissed MacArthur were clearer, although it was evident that the abrupt manner in which he was dismissed was 111 -advised.2

\footnotetext{
I Ib1d., p. 3662 .

2 New York Times, June 1, 1951.
} 
The hearines also necessitated a review of Korean war strategy. They resulted in positive statements by the United states that we would oppose Chinese Communist admission to the United Nations. 'Iruman's determination to contain the war was clearer and this forcefulness removed an excuse for the allies not to contribute more to Korea on the pretext of disapproving of General MacAfthur's tactics and disbelief in the President's ability to control rim. ${ }^{1}$ That the nation wanted peace and desired above all to avold a third world war was demonstrated time and time aijain. As for the conservative Republican views on Korea, the transcripts revealed how illogical was the position of favoring Machrthur's jroposals and at the same time advocating reductions in the number of troops and the amount of money being spent to carry on the war.

The hearings were harmful in several respects. Tradley had testified during the hearings that the prolonged probe of the military situation was endangering the United States and that the military disclosures might incite an attack by the Russians in other spots of the world. ${ }^{2}$ It was undoubtedly true that the Russians could gle an much information from the published reports. Several articles in the lew York Times pointec out what these areas were. The full picture of the division of opinion over Korea between the United States and its allies, as well as between

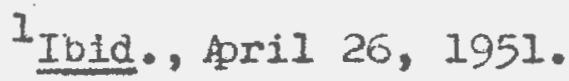

2Military intuation in the Far last, p. 953. 
Machrthur and the administration, was shown. The vagueness of future policy, as charged by the hepublicans, was revealed, along with the fact that we did not consider ourselves strong enough to wage a successful war on a larmer scale. ${ }^{1}$ This vagueness as to future action stemed partially from our lack of concrete knowledge of actual conditions behind the Iron Curtain. Our admission that we were attempting to $\mathrm{kill}$ as many Chinese as possible and that we had many casualties gave inpetus to the Russian propacianda machine. 2

On the other hand, several predicted results of the dismissal did not occur. Porecasts of a hamful effect on the Japanese peace treaty negotiations resultine from the removal did not materialize. Immediately after MacArthur's departure from Japan, John Foster Dulles irformed the Japanese government that our policy had not changed. There were, subsequently, ro ereat obstacles in coming to an asreement on what the treaty should contain. 3 General Ridgway took command of the Par Rast theater and carried out his mission effectively.

Thus the administration's decision to remove PacNcthur had passed before the "hich court of public opinion," as the eneral hinself said it would have to. ${ }^{4}$ In spite

$I_{\text {New York Iimes, May } 27,1951 .}$

2 Ibia., May 13, 1951.

3 Hilitary Situation in the Far East, p. 752 .

${ }^{4}$ Ibid., P. 102. 
105

of the initial uproar over the way the dismissal notice had been given and the turultuous reception given MacArthur on his return to the United States, Truman's views on limitine the war were justified and were followed by the succeeding Republican administration. 


\section{APPENDIX}

Message from Jolnt Chiefs of Stafe to General MacArthur on December 6, 1950

From joint Chlaps of stafe to Comander-in-Chior, Far East, Tokyo, Japan (and other comanders):

1. The President, as of 5 Dec. forwarded a memo to all Cabinet rembers and to the chairman R.S.R.B., administrator B.C.A., director C.I.A., administrator $\mathbb{B}_{*}$..A. and director Selective Service, which reads as follows:

"In the IIght of the present critical international situation, and until furtber witton notice from me, I wish that each one of you would take immediate steps to reduce the number of public speeches pertaining to forelgn or militaxy pollcy made by offlcials of the departments and agencies of the Executive Branch. This applies to oficials in the fleld as well as those in washington.

"No speech, press release, or other public statement concerning foreign policy ghould be releaged until it has recelved clearance from the Deprtment of state.

wo speech, press release, or other statemont concerning ilitary polley should be released until it has recelved clearance from the Department of Defense.

"In addition to the coples submitted to the Departments of State and Defense for clearance, advance coples of speeches and press releases concerming forelgn policy or militaxy policy should be submitted to the white House for information.

mhe purpose of this memerandum is not to curtail the flow of inforation to the American people, but rather to insure that the information made pubilc 18 accurate and fully in accord with the policies of the United States Govermaent.

2. He also forwarded the following to the secretary of State and Secretary of Befense:

"Officiais overseas, inciuaing military comanders and diplomatic representatives, should be ordered to exerclse extreme caution in public statements, to clear all but routine statements with their departments, and to refrain frow direct commication on wllitary or forelgn polley with newspapers, magazines, or other publicity media in the United States.

3. The above is transmitted to you for guidance and appropriate action. 
Excerpts from President Truman's April II Address to the Nation

The whole Communist imperialism is back of the attack on peace in the Par East. It was tie Soviet Union that trained and equipped the fiorth Koreans for aggression. The Chinese Communists massed forty-four well-trained and wellequipped divisions on the Korean frontier. These were the troops they threw into battle when the North Korean Communists were beaten.

The question we have had to $f a c e$ is whether the communist plan of conquest can be stopped without general war. Our Government and other countries associated with us in the United Nations believe that the best chance of stopping it without general war is to meet the attack in Korea and def at it there.

We do not want to see the conflict in Korea extended. We are trying to prevent a world war--not to start one. The best way to do that is to make it plain that we and the other free countries will continue to resist the attack.

But you may ask: Why can't we take other steps to punish the ageressor? Why don't we bomb hanchuria and China itself? Why don't we assist Chinese Nationalist troops to land on the mainland of Crina?

If we were to do these things we would be running a very grave risk of starting a general war. If that were to happen, we would have brousht about the exact situation we are trying to prevent.

If we ifere to do these things, we would become entanEled in a vast conflict on the continent of Asia and our task would become immeasurably more difficult all over the worla.

First of ali, it is clear that our efforts in Koré can blunt the will of the chinese Communists to continue the strugile. The United liations forces have put up a tremendous fight in Korea and have inflicted very heavy casualties on the enemy. Our forces are stronger now than they have been before. These are plain facts which may discourace the Chinese Communists from continuing their attack.

Second, the free world as a whole is crowing in military strength every day. In the United States, in western Europe, and throughout the world, free men are alert to the Soviet threat and are building their defenses. This may discourage the Communist rulers from continuing the war in Korea-and from undertaling new acts of agsression elsewhere.

- I beifeve that we must try to imit the war in Korea for these vital reasons: to make sure that the precious lives of our fighting men are not wasted; to see that the security of our country and the free world is not needessly 
jeopardized, and to prevent a third world war.

I number of events have ade it evident that General MecArthur did not agree with that polley. I have therefore consiebred it essential to relieve General MecArthur so that there would be no doubt or confusion as to the real purpose and ain of our polley.

It was with the deepest personal regret that I found myself compelled to take this action. General MacArthur is one of our greatest military commanders. But the cause of world peace is more important than any individual.

\section{Excerpts from Address of General MacArthur to Jolnt Meeting of Congress on April 19}

Mr. Prenident, Mr. Speaker, distinguished Members of the Congress, I stand on this rostrum with a sense of deep humility and grest pride; humility in the wake of those great American architects of our history who have stood here before me; pride in the reflection that this forum of legielative debate represents human liberty in the purest form yet devised. [Applause]

Here are centered the hopes, and aspirations, and faith of the entire human race.

I do not stand here as advocate for any partisan cause, for the issues are fundanental and reach quite beyond the realm of partisan consideration. They must be resolved on the hichest plane of national intereat if our course is to prove sound and our future protected. I trust, therefore, that you will do me the justice of recelving that which I have to say as solely expressing the considered viowpolnt of a fellow American. I address you with nelther rancor nor bittemess in the fading twilight of iffe ith but one purpose in mind, to serve my country. [Appleuse]

The issues are lobal and so interlocied that to consider the problems of one sector oblivious to those of another is but to court disaster for the whole.

Wh1le Amia is comonly referred to as the gateway to Europe, it is no less true bat Burope is the gateway to As 1a, and the broad influence of the one cannot fall to have 1ta impact upon the other.

There are those who claim our strength is inadequate to protect on both fronts, that we cannot divide our effort. I can think of no greater expression of defeatism. [ADplause. If a potential enemy can divide his strength on two fronts, it is for us to counter hls effort.

Our trategic frontier then shifted to embrace the entire Paciflo Ocean which became a vast noat to protect us as long as we held it. ' Indeed, it acts as a protective shield for all of the Americas and all free lands of the Pacifle Ocean area. We control it to the shores of Asla by a chain of iblands extending in an arc fron the Aleutians to the Marlanas held by us and our froe allies. 
The holding of this littoral defense line in the western Facific is entirely dependent upon holding all segments thereof, for any major breach of that line by an unfriendly power would render vulnerable to determined attack every other segment.

Tits is a military estimate as to which I have yet to find a military leader who will take exception. [Applause.]

For that reason I have strongly reconmended in the past as a mater of military urgency that uncer no circumstances must Formosa fall under Comnunist control. [Applause]

Wile $\dot{I}$ as not consulted prior to the president's dectsion to intervene in support of the Republic of Korea, trat decision, from a military standpoint, proved a sound one. As I say, it proved a sound one, as we hurled back the invader and decimated his forces. Our victory was complete a:d our objectives within reach when Red China intervened with numerically superior ground forces.

This created a new war and an an entirely new situation not contemplated when our forces were committed abainst the North Korean invaders, a situation which called for new decisions in the diplomatic sphere to permit the realistic adjustment of military strategy.

Such decisions have not been forticoming.

While ro man in bis right mind would advocate sending our ground forces into continental China, and such was never given a thought, the new situation did urgently demand a drastic revision of strategic planning if our political ain was to defeat this new enemy as we had defeated tile old. Apart from the milltary need, as I saw it, to neutralize the sanctuary protection given the enemy north of Yalu, I felt that military necessity in the conduct of the war made necessary, first, the intensification of our economic blockade against China; second, the imposition of a naval blockade against the China coast; third, removal of restrictions on air reconnaissance of China's coastal areas and of Manchuria; fourth, removal of restrictions on the forces of the Republic of China on Formosa with logistical support to contribute to their effective operations against the Chinese mainland. [Applause]

In war there is no substitute for victory. There are some who, for varying reasons, would appease Red China. They are blind to history's clear lesson, for history teaches, with unmistakable emphasis, that appeasement but betets new and bloodier war. It points to no single inatance where this end has justifled that means, where appeasement has led to more than a sham peace. Like blackmail, it lays the basis for new and successively ereater demands until, as in blackmail, violence becomes the only other alternative. Why, my soldiers asked of me, surrender military advantages to an enemy in the field? I could not answer. [Applause.] 


\section{BIBLIOGRAPHY}

Burns, Martin. MacArthur: The Reel Story. New Tork: Universal Publishing and Distributing Co., 1951.

Goodrlch, Ieland M. Korea: A Study of United States Policy in the United Nations. New York: Counc1l on Foreign Relations, 1956.

M1Llis, Walter. Arms and the State: Civil-Military Elements in National Pollay. New York: The Twentieth Century Fund, 1958.

Hew York Timeg. 1950-1951.

Rovere, Rlcherd H, and Schlesinger, Arthur M., Jr. The General and the President and the Future of AmerIcan Forelgn Pollcy. Hew York: Farrar, Straus, and Youne, 1951.

Pruman, Haxry $\mathrm{S}$. Menolrs. Vol. II: Years of Trial and kope. New Tork! Doubledas and Co." 1956.

United Nations Becretariat. WThe Question of Koren (1950-1953)." United Nations Backeround Papers. No. 67. March 10, 1954.

U.8. Congressional Record. Vol. XIVII.

U.S. Senate, Comittee on Arwed Services and Comittee on Forelgn Relations. Hearings on the M111tary S1tuation in the Far East. 82 cons., Ist 5ess;, 1951.

Vinacke, Harola. Far Eastern Polltics in the Post-War Perlod. New Tork: Apploton, Century-Crolts, Inc., 1956.

Whtney, Courtney, MacArthus: His Rendezvous Uth Histerr. New York: AIfred A. knopt Co., 1956. 